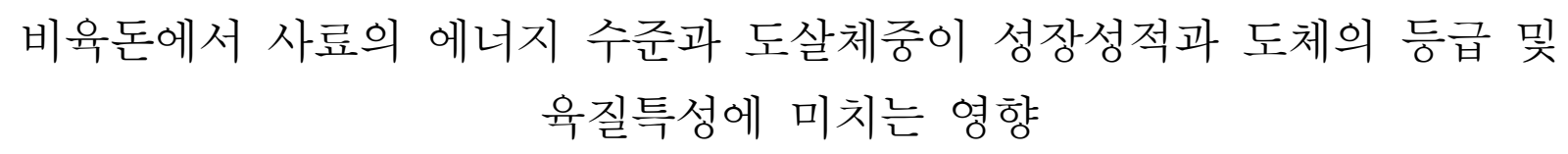

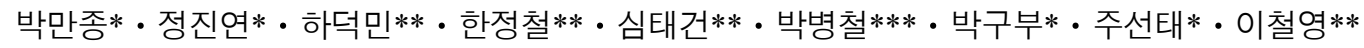

경상대학교 동물자원과학부*, 진주산업대학교 동물생명산업센터**, 씨제이제일제당주식회사***

\title{
Effects of Dietary Energy Level and Slaughter Weight on Growth Performance and Grades and Quality Traits of the Carcass in Finishing Pigs
}

Man Jong Park*, Jin Yeun Jeong*, Duck Min Ha**, Jeong Cheol Han**, Tae Geon Sim**, Byung Chul Park***,

Gu Boo Park*, Seon Tea Joo* and Chul Young Lee**

Division of Animal Science, Gyeongsang National University*,

Regional Animal Industry Center, Jinju National University**, CJ Corp.***

\begin{abstract}
$(\mathrm{Y} \times \mathrm{L}) \times \mathrm{D}$-crossbred gilts and barrows weighing $80.2 \pm 0.2 \mathrm{~kg}$ were fed a "medium-energy" (ME) or "low-energy" (LE) diet (3.2 vs $3.0 \mathrm{M}$ cal $\mathrm{DE} / \mathrm{kg}$ ) and slaughtered at 110,125 , or $138 \mathrm{~kg}$, after which physicochemical and sensory quality traits of major primal cuts of resulting carcasses were analyzed, under a 2 (sex) $\times 2$ (diet) $\times 3$ (slaughter weight; SW) factorial arrangement of treatments. The ADG and ADFI were greater $(\mathrm{P}<0.01)$ in barrows than in gilts and also in 125- and 138-kg vs $110-\mathrm{kg}$ SW. Moreover, ADG and gain:feed were greater in $\mathrm{ME}$ vs $\mathrm{LE}(\mathrm{P}<0.01)$, whereas ADFI was greater in $\mathrm{LE}$ vs $\mathrm{ME}(\mathrm{P}<0.01)$. Backfat thickness, which increased with increasing $\mathrm{SW}(\mathrm{P}<0.01)$, was not affected by sex or diet. Carcass marbling score was greater $(\mathrm{P}<0.01)$ in gilts and LE than in barrows and ME, respectively. Carcass quality grade, which was superior in LE vs ME, was not affected by SW, whereas the yield grade decreased abruptly between 125- and 138-kg SW primarily due to the upper limit of carcass weight imposed on the $\mathrm{A}$ and $\mathrm{B}$ grades. Physicochemical characteristics including $\mathrm{pH}$, drip loss, and variables pertaining to color of belly, ham, and loin were not affected significantly by any of the treatment factors, albeit statistically significant in some cases, in terms of quality criteria. In sensory evaluation, the acceptability of fresh belly was not influenced by any of the treatment factors. Marbling score of fresh ham was greater in LE vs $\mathrm{ME}(\mathrm{P}<0.01)$ and tended to increase between 110 - and $125-\mathrm{kg} \mathrm{SW}(\mathrm{P}=0.10)$; in loin, the increase of this variable between the two $\mathrm{SW}$ was significant $(\mathrm{P}<0.01)$. Following cooking, LE was superior to $\mathrm{ME}$ in the acceptability in belly and ham, but the effect of SW was insignificant in any of the sensory quality traits evaluated in this study in any of the three major primal cuts. In conclusion, the present results suggest that SW can be increased to up to $138 \mathrm{~kg}$ without compromising carcass quality and that LE has some beneficial effects on quality of the whole carcass and the major primal cuts.
\end{abstract}

(Key words : Finishing pig, Slaughter weight, Diet, Carcass, Meat quality)

\section{I. 서 론}

양돈산업에서 비육돈의 출하체중은 육질 및 수익에 영 향을 미치는 중요한 요인으로서 도체등급기준, 유통업자 및 소비자의 요구 등과 같이 생산자가 선택할 수 없는 여 건과 비육돈의 유전적 배경, 영양-사양관리 등과 같은 생산자의 선택 등에 의해 결정된다 $(\mathrm{Kim}$ 등, 2005 ; 이 등, 2006). 따라서 주어진 사회 - 산업적 환경 하에서 교배조합 이 결정되면 비육돈의 출하체중은 영양 특히 사료의 에너 지 수준에 따라 일정 생체중 범위 내에서 조절될 수 있다. 현재 국내에서 널리 쓰이고 있는 종돈은 대부분 유럽 및 미국에서 수입해오는 적육형인데 반해 비육돈의 출하체중
은 구미에서보다 5 15 kg 낮은 $110 \mathrm{~kg}$ 수준을 수년간 유지 해 오고 있다 (Kim 등, 2005; NASS, 2008).

선행연구(이 등, 2006, 2007; 박 등, 2007)에서 본 연구 진은 돼지 도체의 등급이 거의 전적으로 도체중과 등지방 두께에 의해 결정되는 육량등급 기준(농림부, 2007) 하에 서도 $110 \mathrm{~kg}$ 대비 $125 \mathrm{~kg}$ 출하가 오히려 전자보다 경제적 으로도 유리할 수 있다는 연구결과를 보고하였다. 최근 연구 (박 등, 2009)에서는 생체중 약 $80 \mathrm{~kg}$ 의 비육돈에 $\mathrm{NRC}$ (1998)가 권장한 비육돈사료의 에너지 수준 $(3.4 \mathrm{Mcal}$ $\mathrm{DE} / \mathrm{kg}$ )의 $90 \%(3.06 \mathrm{Mcal} \mathrm{DE} / \mathrm{kg}$ )를 함유한 저에너지사료를 급여하고 110,125 , 혹은 $135 \mathrm{~kg}$ 까지 비육하여 도축하였을 때 $125 \mathrm{~kg}$ 혹은 $135 \mathrm{~kg}$ '고체중'에 도축된 비육돈은 $110 \mathrm{~kg}$

Corresponding author : C. Young Lee, Regional Animal Industry Center, Jinju National University, Jinju 660-758 Tel: 055-751-3285, Fax: 055-753-4422, E-mail: cylee@jinju.ac.kr 
에 도축된 비육돈에 비해 성장효율, 등심, 뒷다리 및 등심 등과 같은 주요 부분육의 수율 및 이화학적 특성상 가시 적인 차이가 없음이 밝혀졌다. 또한 이들 공시돈으로부터 산출된 삼겹살 신선육의 지방층 : 근육층의 균형은 $125 \mathrm{~kg}$ 도축 시 가장 우수하였으나 주요 부위 가열육의 관능품질 특성은 도살체중의 영향을 받지 않았다. 그러나 이들 선 행연구에서는 2008년부터 전국적으로 돼지 도체에 적용되 기 시작한 육질등급 (농림부, 2007), 육질관련 변수, 사료의 에너지 수준 및 생산효율 간의 상호관계에 대해서는 조사 되지 않았다. 따라서 본 연구는 생체중 $80 \mathrm{~kg}$ 의 암퇘지와 거세돼지에 $3.2 \mathrm{Mcal}$ (중에너지) 혹은 $3.0 \mathrm{Mcal}$ (저에너지) $\mathrm{DE} / \mathrm{kg}$ 의 에너지를 함유한 두 종류의 사료를 급여하고, 110,125 , 혹은 $138 \mathrm{~kg}$ 에 도살하여 이들 처리요인이 성장 효율, 도체의 육량등급과 육질등급 및 주요 부분육의 관 능평가 품질특성에 미치는 영향을 조사하여 적정 에너지 수준과 도살체중을 유추하고 바람직한 도체품질 기준에 대해 고찰하고자 수행되었다.

\section{ㅍ. 재료 및 방법}

\section{1. 공시돈}

본 실험은 약 150 일령의 (Yorkshire $\times$ Landrace $) \times$ Duroc 교잡종 암퇘지와 거세돼지 각각 96두씩 총 192두의 비육 돈 (개시체중 : $80.2 \pm 0.2 \mathrm{~kg}$ )을 이용하여 2(성; 암 및 거세) $\times 2$ [사료 ; $3.2 \mathrm{Mcal}$ (“중에너지”) 및 $3.0 \mathrm{Mcal}$ ("저에너지”) $\mathrm{DE} / \mathrm{kg}$ ) $\times 3$ (도살체중; 110,125 및 $138 \mathrm{~kg}$ ) 요인분석 실험 설계 하에 수행되었다. 모든 공시돈이 짧은 기간 내에 도 축될 수 있게 하기 위하여 먼저 $138 \mathrm{~kg}$ 에 도축될 암퇘지 32 두와 거세돼지 32 두를 돈방당 4 두씩 총 16 돈방에 배치 하고, 3주 후에 $125 \mathrm{~kg}$ 에 도축될 암퇘지와 거세돼지 총 64 두를 배치한 다음 다시 3주 후에 최종적으로 64 두의 공시 돈을 임의로 배치하였다. 공시돈은 두당 $1.6 \mathrm{~m}^{2}$ 의 공간과 음용수 및 배정된 사료 (Table 1)가 자유로이 제공되었다. 생체중은 실험개시일, 실험개시 후 매 3 주째 되는 날 및 출하일에 측정하였다.

\section{2. 도축 및 등급판정}

공시돈이 당초에 정해졌던 출하체중에 근접하면 전술한 바 (박 등, 2009)와 같이 부경양돈농협 공판장에 수송하여 출하 이튿날에 도축하고 등급판정사에 의해 등지방두께, 육색, 상강도 등의 육질특성과 육질등급 및 육량등급 (농 림부, 2007)이 판정되었다.

\section{3. 부분육 분석 : 이화학적 특성 및 관능검사}

임의로 선택된 두 날짜에 도살된 총 72두 (36두/일; 6두/ 실험구)의 공시돈 냉도체로부터는 7개의 주요부위 (농림부, 2005)와 "갈매기살"을 분할하여 무게를 측정하고, 삼겹살,
Table 1. Composition of the diet (as-fed basis)

\begin{tabular}{lcc}
\hline Item & $\begin{array}{c}\text { Medium-Energy } \\
\text { Diet }\end{array}$ & $\begin{array}{c}\text { Low-Energy } \\
\text { Diet }\end{array}$ \\
\hline Ingredients, \% & & \\
Corn & 67.89 & 49.21 \\
Wheat bran & 4.86 & 30.00 \\
Soybean meal (44\%) & 18.06 & 11.78 \\
Rapeseed meal & 3.00 & 3.00 \\
Molasses & 4.00 & 4.00 \\
Limestone & 0.67 & 0.73 \\
Dicalcium phosphate & 0.92 & 0.60 \\
Salt & 0.25 & 0.25 \\
Vitamin premix & 0.10 & 0.10 \\
Mineral premix & 0.10 & 0.10 \\
L-Lysine & 0.15 & 0.23 \\
Total & 100.00 & 100.00 \\
\hline Calculated chemical composition & & \\
DE, Mcal/kg & 3.20 & 3.00 \\
Crude protein, \% & 15.5 & 15.0 \\
Lysine, \% & 0.90 & 0.90 \\
Crude fat, \% & 3.19 & 3.32 \\
Crude fiber, \% & 3.94 & 5.05 \\
Crude ash, \% & 4.58 & 5.03 \\
Ca, \% & 0.60 & 0.67 \\
P, \% & 0.55 & 0.61 \\
\hline
\end{tabular}

${ }^{a}$ Provided per $\mathrm{kg}$ of diet: 8,100 IU vitamin A, 1,200 IU vitamin $\mathrm{D}_{3}$, 45 IU vitamin $\mathrm{E}, 2.25 \mathrm{mg}$ vitamin $\mathrm{K}, 1.5 \mathrm{mg}$ thiamin, 0.6 $\mathrm{mg}$ riboflavin, $2.55 \mathrm{mg}$ pyridoxine, $0.03 \mathrm{mg}$ vitamin $\mathrm{B}_{12}, 19.5 \mathrm{mg}$ pantothenic acid, $39 \mathrm{mg}$ niacin, $0.09 \mathrm{mg}$ biotin, and $0.75 \mathrm{mg}$ folic acid.

b Provided per $\mathrm{kg}$ of diet: $102.7 \mathrm{mg} \mathrm{FeSO}_{4}, 0.442 \mathrm{mg} \mathrm{CoSO}_{4}, 67$ $\mathrm{mg} \mathrm{CuSO}$, $54.18 \mathrm{mg} \mathrm{MnSO}_{4}, 69 \mathrm{mg} \mathrm{ZnSO}_{4}, 0.546 \mathrm{mg} \mathrm{CaIO}$, and $0.338 \mathrm{mg} \mathrm{Na} 2 \mathrm{SeO}_{3}$.

뒷다리 및 등심 신선육 및 이들 부위의 가열육에 대해서 는 전술한 바 (Lee 등, 2002; 이 등, 2006; 박 등, 2007, 2009)와 같이 이화학적 특성과 관능평가를 수행하였다.

\section{4. 통계분석}

모든 측정치, 수치화된 육질 및 육량 등급 및 수치화된 육질관련 변수는 SAS (1996)의 General Linear Model Procedure를 이용하여 분석하였다. 사료섭취량과 사료효율을 제외한 모든 변수에서 공시돈이 실험단위이었고, 돈방 단 위로 측정되었던 전자에서는 돈방이 실험단위이었으며, 분석 Model에는 성, 사료 및 도살체중과 이들 간의 모든 가능한 상호작용이 고정오차로 삽입되었다.

\section{III. 결 과}

\section{1. 성장성적}

일당증체량은 거세돼지 $(0.94 \mathrm{~kg})$ 가 암퇘지 $(0.84 \mathrm{~kg})$ 보다 컸고 $(\mathrm{P}<0.01), 3,200 \mathrm{kcal} \mathrm{DE} / \mathrm{kg}$ 의 에너지를 함유한 사료 (“중에너지”)를 급여 받은 구 $(0.93 \mathrm{~kg})$ 가 $3,000 \mathrm{kcal} \mathrm{DE} / \mathrm{kg}$ 
의 사료 (“저에너지”) 구 $(0.84 \mathrm{~kg})$ 보다 컸으며 $(\mathrm{P}<0.01), 110$ $\mathrm{kg}$ 도살체중 구 $(0.84 \mathrm{~kg})$ 에 비해 $125 \mathrm{~kg}$ 구 $(0.92 \mathrm{~kg})$ 및 138 $\mathrm{kg}$ 구 $(0.91 \mathrm{~kg})$ 가 컸다 $(\mathrm{P}<0.01$; Table 2$)$. 일당사료섭취량은 일당증체량에서와 같이 거세돼지 $(3.68 \mathrm{~kg})$ 가 암퇘지 $(3.35$ $\mathrm{kg})$ 보다 컸으나 $(\mathrm{P}<0.01)$, 두 공시사료 간에는 차이가 없 었고(중에너지 대비 저에너지: 3.50 vs $3.53 \mathrm{~kg}$ ), $125 \mathrm{~kg}$, $138 \mathrm{~kg}$ 및 $110 \mathrm{~kg}$ 도살체중 구 순으로 컸다 (각각 3.65 , 3.54 및 $3.35 \mathrm{~kg} ; \mathrm{P}<0.01)$. 본 변수는 암퇘지에서는 $125 \mathrm{~kg}$ 와 $138 \mathrm{~kg}$ 도살체중 구 (각각 3.51 및 $3.46 \mathrm{~kg}$ ) 간에 차이 없이 $110 \mathrm{~kg}$ 구 $(3.08 \mathrm{~kg})$ 보다 컸던 $(\mathrm{P}<0.01)$ 반면 거세돼지 에서는 $125 \mathrm{~kg}$ 구 $(3.79 \mathrm{~kg})$ 가 $110 \mathrm{~kg}$ 구 $(3.63 \mathrm{~kg})$ 및 $138 \mathrm{~kg}$ 구 $(3.62 \mathrm{~kg})$ 보다 컸다 $(\mathrm{P}<0.01)$. 또한 본 변수는 중에너지 사료를 급여했을 때는 $125 \mathrm{~kg}$ 도살체중 구 $(3.69 \mathrm{~kg})$ 가 110 $\mathrm{kg}$ 및 $138 \mathrm{~kg}$ 구 (각각 3.39 및 $3.42 \mathrm{~kg}$ ) 보다 컸으나 $(\mathrm{P}<0.01)$ 저에너지 사료를 급여했을 때는 $125 \mathrm{~kg}$ 및 $138 \mathrm{~kg}$ 구 (각각 3.61 및 $3.66 \mathrm{~kg}$ ) 간에 차이 없이 $110 \mathrm{~kg}$ 구 $(3.31$ $\mathrm{kg})$ 보다 높았다 $(\mathrm{P}<0.01)$. 사료효율에서는 두 성 및 세 도 살체중 구 간에는 차이 없이 중에너지 구 $(0.268)$ 가 저에너 지 구 $(0.239)$ 보다 높았다 $(\mathrm{P}<0.01)$. 표적체중에 보정된 등지 방두께는 거세돼지 $(23.4 \mathrm{~mm})$ 가 암퇘지 $(21.2 \mathrm{~mm})$ 보다 컸고 $(\mathrm{P}<0.01)$, 도살체중이 증가할수록 컸다 $(\mathrm{P}<0.01 ; 110,125$ 및 $138 \mathrm{~kg}$ 도살체중 구: 각각 $19.9,22.5$ 및 $24.4 \mathrm{~mm}$ ). 본 변수는 중에너지 사료 $(22.7 \mathrm{~mm})$ 와 저에너지 사료 $(21.8$ $\mathrm{mm})$ 구 간에는 차이가 없었으나 $(\mathrm{P}=0.11)$, 전자를 급여했 을 때는 두 도살체중구간 $(110 \sim 125 \mathrm{~kg}$ 및 $125 \sim 138 \mathrm{~kg})$ 사이 모두 증가하였으나 (각각 $\mathrm{P}<0.01$ 및 $\mathrm{P}<0.05$; 각각의 도살체 중에서의 등지방두께 : $19.0,23.6 \mathrm{~mm}$ 및 $25.6 \mathrm{~mm}$ ) 후자를 급여했을 때는 도살체중이 $110 \mathrm{~kg}$ 으로부터 $138 \mathrm{~kg}$ 까지 증 가돼야 비로소 본 변수가 증가하였다 $(\mathrm{P}<0.05$; 각각의 도 살체중에서의 등지방두께: 20.8, 21.4 및 $23.2 \mathrm{~mm}$ ).

\section{2. 도체의 품질특성 및 등급}

도체의 육색은 거의 모든 공시돈이 $1^{+}$육질등급 기준에 해당하는 No. 3 5를 받아 본 육질변수를 수치화해도 성, 사료 및 도살체중 구 간 차이가 없었다 (Table 3). 도체의 지방침착도 (marbling)에서는 $1^{+} \& 1,2$ 및 3 등급에 해당하 는 성적에 각각 4, 2 및 1점을 부여한 다음 처리요인의 유의성 여부를 검정하였다. 본 육질변수는 거세돼지 (2.10) 가 암퇘지 (1.76) 보다 높았고 $(\mathrm{P}<0.01)$, 저에너지 구 (2.11)가 중에너지 구 $(1.75)$ 보다 높았으나 $(\mathrm{P}<0.01)$ 세 출하체중 구 간에는 차이가 없었다. 본 변수는 또한 암퇘지에서는 중 에너지 구 (1.72)와 저에너지 구(1.80) 간에 차이가 없었으 나 거세돼지에서는 저에저지 구 (2.42)가 중에너지 구 (1.79) 보다 현저히 높았다 $(\mathrm{P}<0.01) .1^{+}, 1,2$ 및 3 최종 육 질등급에 대해서는 각각 $4,3,2$ 및 1 점을 부여한 다음 고 정오차에 대한 유의성 여부를 검정하였다. 육질등급은 거 세돼지 (2.92)가 암퇘지 (2.65) 보다 높았고 $(\mathrm{P}<0.01)$, 저에너 지 구 (2.90)가 중에저지 구 $(2.67)$ 보다 높았으며 $(\mathrm{P}<0.01)$, 암퇘지에서는 중에너지 구(2.65)와 저에너지 구 (2.65) 간
차이가 없었으나 거세돼지에서는 저에너지 구 (3.16)가 중 에너지 구 (2.69) 보다 높았다 $(\mathrm{P}<0.01)$. 그러나 도살체중은 본 변수에 전혀 영향을 미치지 않았다 $(110,125$ 및 $138 \mathrm{~kg}$ 도살체중 구: 각각 $2.83,2.74$ 및 2.79). 이와는 대조적으로 $\mathrm{A}, \mathrm{B}, \mathrm{C}$ 및 $\mathrm{D}$ 육량등급에 대해 육질등급에서와 같이 분 산분석을 하면 도살체중이 $110 \mathrm{~kg}(3.25)$ 에서 $125 \mathrm{~kg}(2.92)$ 으로 증가할 때는 본 변수가 다소 낮아졌으나 $(\mathrm{P}<0.05)$ 도 살체중을 $138 \mathrm{~kg}(1.21)$ 까지 증가시켰을 때는 매우 낮아졌 다. 또한 육량등급은 암퇘지에서는 중에너지 구 (2.42)와 저에너지 구 (2.59) 간 차이가 없었으나 $(\mathrm{P}=0.27)$ 거세돼지 에서는 중에너지 구 (2.56)가 저에너지 구 (2.27) 보다 다소 높은 경향 $(\mathrm{P}=0.06)$ 을 나타내었다. 도살체중과 육량등급과 의 관계를 그림으로 표시하면 (Fig. 1), 성에 관계없이 도 살체중 $103 \mathrm{~kg}$ 으로부터 $125 \sim 130 \mathrm{~kg}$ 까지는 대부분의 공시돈 이 $\mathrm{A}$ 혹은 $\mathrm{B}$ 등급을 받았으나 도살체중 $130 \mathrm{~kg}$ 이상에서 는 대부분 '과중량' 도체가 산출되어 $\mathrm{C}$ 혹은 $\mathrm{D}$ 등급 도체 로 전락하였다.

\section{3. 부분육의 수율 및 이화학적 특성}

도체중은 당연히 도살체중이 증가할수록 증가하였고 $(\mathrm{P}<0.01)$, 거세돼지가 암퇘지보다 컸으며 $(\mathrm{P}<0.05)$, 저에너 지 구가 중에너지 구보다 다소 컸는데 $(\mathrm{P}<0.01)$ 이는 이들 실험구 간 도살체중 차이에 기인하였다(Table 4). 도체율 은 거세돼지에서는 도살체중 구 간 차이가 없었으나 암퇘 지에서는 $125 \mathrm{~kg}$ 구가 110 및 $138 \mathrm{~kg}$ 구보다 각각 $5 \%$ 및 $1 \%$ 유의수준으로 낮았다. 총 정육 중량은 도살체중이 증 가할수록 증가하였고 $(\mathrm{P}<0.01)$, 저에너지 구가 중에너지 구 보다 다소 높았는데 $(\mathrm{P}<0.05)$ 이는 전자가 후자보다 도살 체중과 도체중이 컸기 때문이었다. 정육율은 암퇘지(45.0 $\%)$ 가 거세돼지 $(43.6 \%)$ 보다 높았다 $(\mathrm{P}<0.01)$. 총 정육 중량 대비 앞다리, 목살, 등심, 안심, 갈비, 삼겹살, 뒷다리 및 “갈매기살” (“Seagull”)의 중량 비율 (primal cut percentage) 은 부분육에 따라 성, 사료, 도살체중, 혹은 이들 간의 상 호작용의 유의성이 검출되었다. 그러나 이들 부분육 비율 에서 실험구 간 수치상의 차이는 크지 않았기 때문에 대 체로 큰 의미를 부여할 수는 없었으나 국내에서 가장 선

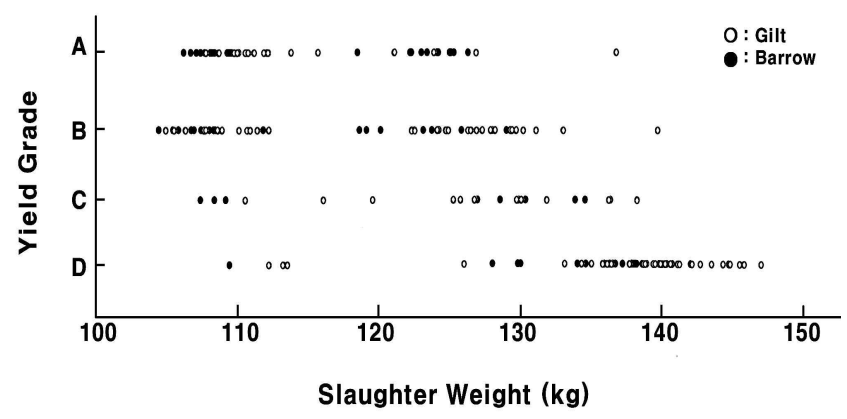

Fig. 1. Distribution of the carcass yield grades of finishing gilts and barrows: effect of the slaughter weight. 
Table 2. Effects of dietary energy level and slaughter weight on growth performance of finishing gilts and barrows

\begin{tabular}{|c|c|c|c|c|c|c|c|c|c|c|c|c|c|c|}
\hline \multirow{3}{*}{ Item } & \multicolumn{6}{|c|}{ Gilts } & \multicolumn{6}{|c|}{ Barrows } & \multirow{3}{*}{$\begin{array}{l}\text { Pooled } \\
\text { SE }\end{array}$} & \multirow{3}{*}{$\begin{array}{l}\text { Significance } \\
(\mathrm{S}, \mathrm{D}, \mathrm{SW})^{\mathrm{a}}\end{array}$} \\
\hline & \multicolumn{3}{|c|}{$3,200 \mathrm{kcal} \mathrm{DE} / \mathrm{kg}$} & \multicolumn{3}{|c|}{$3,000 \mathrm{kcal} \mathrm{DE} / \mathrm{kg}$} & \multicolumn{3}{|c|}{$3,200 \mathrm{kcal} \mathrm{DE} / \mathrm{kg}$} & \multicolumn{3}{|c|}{$3,000 \mathrm{kcal} \mathrm{DE} / \mathrm{kg}$} & & \\
\hline & $110 \mathrm{~kg}$ & $125 \mathrm{~kg}$ & $138 \mathrm{~kg}$ & $110 \mathrm{~kg}$ & $125 \mathrm{~kg}$ & $138 \mathrm{~kg}$ & $110 \mathrm{~kg}$ & $125 \mathrm{~kg}$ & $138 \mathrm{~kg}$ & $110 \mathrm{~kg}$ & $125 \mathrm{~kg}$ & $138 \mathrm{~kg}$ & & \\
\hline Initial $\mathrm{wt}^{\mathrm{b}}, \mathrm{kg}$ & 80.2 & 80.0 & 79.9 & 80.5 & 80.4 & 79.9 & 80.3 & 79.9 & 80.0 & 80.5 & 80.4 & 80.5 & 0.9 & \\
\hline Final $\mathrm{wt}^{\mathrm{b}}, \mathrm{kg}$ & 107.8 & 124.5 & 135.0 & 107.1 & 125.2 & 138.5 & 109.6 & 125.6 & 138.3 & 111.2 & 127.9 & 140.9 & 0.8 & $\mathrm{~S}^{* *}, \mathrm{D}^{* *}, \mathrm{SW}^{* *}$ \\
\hline $\mathrm{ADG}^{\mathrm{b}}, \mathrm{kg}$ & 0.82 & 0.92 & 0.93 & 0.72 & 0.84 & 0.81 & 0.94 & 1.03 & 0.98 & 0.89 & 0.88 & 0.91 & 0.03 & $\mathrm{~S}^{* *}, \mathrm{D}^{* *}, \mathrm{SW}^{* *}$ \\
\hline $\mathrm{ADFI}^{\mathrm{c}}, \mathrm{kg}$ & 3.14 & 3.59 & 3.32 & 3.02 & 3.43 & 3.61 & 3.65 & 3.79 & 3.52 & 3.60 & 3.79 & 3.72 & 0.04 & $\mathrm{~S}^{* *}, \mathrm{SW}^{* *}, \mathrm{~S} \times \mathrm{SW}^{* *}, \mathrm{D} \times \mathrm{SW}^{* *}$ \\
\hline Gain:feed ${ }^{\mathrm{c}}$ & 0.261 & 0.256 & 0.281 & 0.239 & 0.246 & 0.226 & 0.259 & 0.272 & 0.279 & 0.247 & 0.233 & 0.244 & 0.009 & $\mathrm{D}^{* *}$ \\
\hline Backfat ${ }^{b, d}, \mathrm{~mm}$ & 17.6 & 22.5 & 25.9 & 19.0 & 20.0 & 22.0 & 20.4 & 24.6 & 25.3 & 22.6 & 22.9 & 24.4 & 1.0 & $\mathrm{~S}^{* *}, \mathrm{SW}^{* *}, \mathrm{D} \times \mathrm{SW}^{* *}$ \\
\hline
\end{tabular}

a $\mathrm{S}$, sex; D, diet; SW, slaughter weight.

Data are means of 16 animals in each $\mathrm{S} \times \mathrm{D} \times \mathrm{SW}$ combination.

c Data are means of four pens.

d Targeted SW-adjusted average of the measurements between the $11^{\text {th }}$ and $12^{\text {th }}$ ribs and between the last rib and the $1^{\text {st }}$ lumbar.

* $\mathrm{P}<0.05$. ** $\mathrm{P}<0.01$.

Table 3. Effects of dietary energy level and slaughter weight on carcass quality traits of finishing gilts and barrows

\begin{tabular}{|c|c|c|c|c|c|c|c|c|c|c|c|c|c|c|}
\hline \multirow{3}{*}{ Item } & \multicolumn{6}{|c|}{ Gilts } & \multicolumn{6}{|c|}{ Barrows } & \multirow{3}{*}{$\begin{array}{l}\text { Pooled } \\
\text { SE }\end{array}$} & \multirow{3}{*}{$\begin{array}{l}\text { Significance } \\
(\mathrm{S}, \mathrm{D}, \mathrm{SW})^{\mathrm{a}}\end{array}$} \\
\hline & \multicolumn{3}{|c|}{$3,200 \mathrm{kcal} \mathrm{DE} / \mathrm{kg}$} & \multicolumn{3}{|c|}{$3,000 \mathrm{kcal} \mathrm{DE} / \mathrm{kg}$} & \multicolumn{3}{|c|}{$3,200 \mathrm{kcal} \mathrm{DE} / \mathrm{kg}$} & \multicolumn{3}{|c|}{$3,000 \mathrm{kcal} \mathrm{DE} / \mathrm{kg}$} & & \\
\hline & $110 \mathrm{~kg}$ & $125 \mathrm{~kg}$ & $138 \mathrm{~kg}$ & $110 \mathrm{~kg}$ & $125 \mathrm{~kg}$ & $138 \mathrm{~kg}$ & $110 \mathrm{~kg}$ & $125 \mathrm{~kg}$ & $138 \mathrm{~kg}$ & $110 \mathrm{~kg}$ & $125 \mathrm{~kg}$ & $138 \mathrm{~kg}$ & & \\
\hline Meat color $^{b}$ & 3.75 & 4.00 & 4.00 & 4.00 & 4.00 & 3.87 & 4.00 & 4.00 & 4.00 & 4.00 & 3.88 & 4.00 & 0.07 & \\
\hline Marbling $^{c}$ & 1.81 & 1.80 & 1.53 & 1.81 & 1.67 & 1.93 & 1.94 & 1.88 & 1.56 & 2.33 & 2.25 & 2.67 & 0.18 & $\mathrm{~S}^{* *}, \mathrm{D}^{* *}, \mathrm{~S} \times \mathrm{D}^{* *}$ \\
\hline Quality grade $^{\mathrm{d}}$ & 2.69 & 2.73 & 2.53 & 2.63 & 2.60 & 2.73 & 2.89 & 2.63 & 2.56 & 3.13 & 3.00 & 3.33 & 0.15 & $\mathrm{~S}^{* *}, \mathrm{D}^{* *}, \mathrm{~S} \times \mathrm{D}^{* *}$ \\
\hline Yield grade $^{\mathrm{e}}$ & 3.19 & 2.93 & 1.13 & 3.44 & 3.20 & 1.13 & 3.63 & 2.69 & 1.38 & 2.73 & 2.88 & 1.20 & 0.19 & $\mathrm{SW}^{* *}, \mathrm{~S} \times \mathrm{D}^{*}$ \\
\hline
\end{tabular}

${ }^{a} \mathrm{~S}$, sex; D, diet; SW, slaughter weight.

${ }^{\mathrm{b}}$ No. $3 \sim 5$, No. 2 or 6 , and No. 1 or 7 of the MAF color standard [MAF (농림부), 2007] corresponding to the quality grades $1^{+} \& 1,2$, and 3 were assigned 4,2 , and 1 points of an arbitrary grade unit, respectively.

${ }^{c}$ No. 4 or 5 , No. 2 or 3 , and No. 1 of the MAF marbling standard [MAF (농림부), 2007] corresponding to the quality grades $1^{+}, 1$, and $2 \& 3$ were assigned 4, 2, and 1 points of an arbitrary grade unit, respectively.

d Grades $1^{+}, 1,2$, and 3 [MAF (농림부), 2007] were assigned 4, 3, 2, and 1 points of an arbitrary grade unit, respectively.

${ }^{\mathrm{e}}$ Grades $\mathrm{A}, \mathrm{B}, \mathrm{C}$, and $\mathrm{D}$ were assigned $4,3,2$, and 1 points of an arbitrary grade unit, respectively.

b,c,d,e Data are means of 16 animals in each $\mathrm{S} \times \mathrm{D} \times \mathrm{SW}$ combination.

* $\mathrm{P}<0.05$. ** $\mathrm{P}<0.01$. 
Table 4. Effects of dietary energy level and slaughter weight on the primal yield of finishing gilts and barrows

\begin{tabular}{|c|c|c|c|c|c|c|c|c|c|c|c|c|c|c|}
\hline \multirow{3}{*}{ Item } & \multicolumn{6}{|c|}{ Gilts } & \multicolumn{6}{|c|}{ Barrows } & \multirow{3}{*}{$\begin{array}{c}\text { Pooled } \\
\text { SE }\end{array}$} & \multirow{3}{*}{$\begin{array}{l}\text { Significance } \\
(\mathrm{S}, \mathrm{D}, \mathrm{SW})^{\mathrm{a}}\end{array}$} \\
\hline & \multicolumn{3}{|c|}{$3,200 \mathrm{kcal} \mathrm{DE} / \mathrm{kg}$} & \multicolumn{3}{|c|}{$3,000 \mathrm{kcal} \mathrm{DE} / \mathrm{kg}$} & \multicolumn{3}{|c|}{$3,200 \mathrm{kcal} \mathrm{DE} / \mathrm{kg}$} & \multicolumn{3}{|c|}{$3,000 \mathrm{kcal} \mathrm{DE} / \mathrm{kg}$} & & \\
\hline & $110 \mathrm{~kg}$ & $125 \mathrm{~kg}$ & $138 \mathrm{~kg}$ & $110 \mathrm{~kg}$ & $125 \mathrm{~kg}$ & $138 \mathrm{~kg}$ & $110 \mathrm{~kg}$ & $125 \mathrm{~kg}$ & $138 \mathrm{~kg}$ & $110 \mathrm{~kg}$ & $125 \mathrm{~kg}$ & $138 \mathrm{~kg}$ & & \\
\hline Carcass $\mathrm{wt}^{\mathrm{b}}, \mathrm{kg}$ & 80.4 & 91.2 & 102.3 & 81.2 & 91.9 & 105.1 & 81.1 & 94.3 & 101.3 & 83.2 & 95.2 & 106.1 & 1.1 & $\mathrm{~S}^{*}, \mathrm{D}^{* *}, \mathrm{SW}^{* *}$ \\
\hline Dressing $^{\mathrm{b}}, \%$ & 74.6 & 73.2 & 75.8 & 75.8 & 73.5 & 75.9 & 74.0 & 75.0 & 73.2 & 74.8 & 74.4 & 75.3 & 0.8 & $\mathrm{~S} \times \mathrm{SW}^{*}$ \\
\hline Total lean ${ }^{\mathrm{c}}, \mathrm{kg}$ & 46.4 & 56.2 & 60.9 & 48.8 & 55.7 & 63.2 & 46.1 & 56.2 & 58.6 & 47.8 & 55.7 & 61.9 & 1.2 & $\mathrm{D}^{*}, \mathrm{SW}^{* *}$ \\
\hline Primal yield ${ }^{\mathrm{c}}, \%$ & 43.3 & 44.7 & 45.8 & 45.4 & 45.3 & 45.8 & 42.7 & 44.9 & 42.3 & 43.5 & 44.2 & 44.4 & 0.8 & $\mathrm{~S} * *$ \\
\hline \multicolumn{15}{|c|}{ Primal cut percentage $^{c}$} \\
\hline Shoulder & 16.4 & 16.3 & 16.6 & 16.5 & 16.8 & 16.6 & 17.3 & 16.5 & 16.9 & 16.4 & 16.3 & 16.8 & 0.3 & \\
\hline Neck & 8.9 & 8.8 & 9.3 & 9.3 & 9.3 & 9.9 & 9.1 & 9.5 & 9.3 & 9.8 & 9.4 & 9.5 & 0.2 & $\mathrm{D}^{* *}$ \\
\hline Loin & 12.5 & 11.7 & 11.7 & 13.0 & 12.4 & 12.7 & 11.7 & 11.9 & 10.6 & 12.5 & 12.1 & 12.1 & 0.3 & $\mathrm{~S}^{* *}, \mathrm{D}^{* *}, \mathrm{SW}^{*}$ \\
\hline Tenderloin & 1.9 & 1.8 & 1.8 & 1.8 & 1.8 & 1.8 & 1.8 & 1.8 & 1.7 & 1.8 & 1.7 & 1.7 & 0.1 & $\mathrm{~S}^{*}$ \\
\hline Rib & 8.2 & 7.9 & 8.1 & 7.4 & 7.4 & 7.8 & 8.4 & 7.9 & 8.5 & 7.7 & 7.6 & 7.2 & 0.2 & $\mathrm{D}^{* *}, \mathrm{~S} \times \mathrm{D} \times \mathrm{SW}^{*}$ \\
\hline Belly & 20.0 & 21.1 & 20.8 & 19.1 & 20.1 & 20.1 & 21.2 & 21.3 & 21.9 & 20.9 & 21.8 & 21.5 & 0.5 & $\mathrm{~S}^{* *}$ \\
\hline Ham & 31.6 & 31.9 & 31.3 & 32.5 & 31.8 & 30.5 & 30.0 & 30.7 & 30.5 & 30.4 & 30.7 & 30.8 & 0.5 & $\mathrm{~S}^{* *}$ \\
\hline "Seagull" & 0.5 & 0.5 & 0.5 & 0.4 & 0.5 & 0.5 & 0.5 & 0.5 & 0.5 & 0.5 & 0.5 & 0.4 & 0.02 & $\mathrm{~S}^{*}, \mathrm{D}^{* *}$ \\
\hline Total & 100.0 & 100.0 & 100.1 & 100.0 & 100.1 & 99.9 & 100.0 & 100.1 & 99.9 & 100.0 & 100.1 & 100.0 & - & \\
\hline
\end{tabular}

${ }^{a}$ S, sex; D, diet; SW, slaughter weight.

${ }^{b}$ Data are means of 16 animals in each $\mathrm{S} \times \mathrm{D} \times \mathrm{SW}$ combination.

${ }^{c}$ Data are means of six animals in each $\mathrm{S} \times \mathrm{D} \times \mathrm{SW}$ combination.

* $\mathrm{P}<0.05$.

** $\mathrm{P}<0.01$. 
호되는 삼겹살의 비율이 암퇘지 (20.2\%) 보다 거세돼지 (21.4\%)에서 높았고 $(\mathrm{P}<0.01)$, 도살체중이 증가할수록 본 변수가 증가하는 경향 $(\mathrm{P}=0.07)$ 은 주목할 만하였다 $(110$, 125 및 $138 \mathrm{~kg}$ 도살체중 구: 각각 20.3, 21.0 및 21.1\%).

삼겹살 근육층의 명도 $\left(\mathrm{CIE} \mathrm{L} \mathrm{L}^{*}\right)$ 는 저에너지 구 (55.1)가 중에너지 구 (49.3)보다 높았고, 삼겹살 지방층의 명도는 거세돼지 구(79.5)와 저에너지 구 (79.7)가 각각 암퇘지 구 (78.6) 및 중에너지 구 (78.5) 보다 높았다 $(\mathrm{P}<0.01$; Table 5). 삼겹살 근육층의 적색도 $\left(\mathrm{a}^{*}\right)$ 는 성, 사료 혹은 도살체중의 영향을 받지 않았고, 지방층의 황색도 $\left(\mathrm{b}^{*}\right)$ 는 저에너지 구 (4.89)가 중에너지 구 (4.02) 보다 높았다 $(\mathrm{P}<0.01)$. 삼겹살 근육층의 $\mathrm{pH}$ 는 도살체중이 $110 \mathrm{~kg}$ (6.38)으로부터 $125 \mathrm{~kg}$ (6.31)으로 증가되면서 다소 감소하였으나 $(\mathrm{P}<0.05) 138 \mathrm{~kg}$ (6.29)으로 증가시켰을 때는 더 이상 감소하지 않았다. 본 부위의 수분 함량은 암퇘지 $(48.1 \%)$ 가 거세돼지 $(43.7 \%)$ 보 다 $4.4 \%$ 높았고 $(\mathrm{P}<0.01)$, 역으로 지방 함량은 거세돼지 $(38.7 \%)$ 가 암퇘지 $(34.5 \%)$ 보다 비슷한 수치 $(4.2 \%)$ 만큼 높 았다 $(\mathrm{P}<0.05)$.

뒷다리의 명도는 암퇘지에서는 중에너지 구 (44.0) 보다 저에너지 구 $(46.8)$ 에서 높았으나 $(\mathrm{P}<0.05)$ 거세돼지에서는 두 사료 구 간 차이가 없었다 $(47.0 \mathrm{vs} 46.0)$. 본 부위의 적 색도는 성, 사료 혹은 도살체중 구 간 차이가 없었고 $\mathrm{pH}$ 는 중에너지 구 (5.80)가 저에너지 구 (5.69) 보다 다소 높았 다 $(\mathrm{P}<0.05)$. 보수력 (water holding capacity)은 성, 사료 혹 은 도살체중의 영향이 없었다. 육즙참출율은 암퇘지에서 는 중에너지 구 (1.14)가 저에너지 구 (1.74) 보다 낮았고 거 세돼지에서는 역으로 중에너지 구(1.58)가 저에너지 구 $(0.80)$ 보다 높았으나 모든 실험구에서 정상육의 한계치인 $5 \%$ (Joo 등, 1999) 보다는 훨씬 낮은 수치를 나타내었다. 가열감량은 성, 사료 및 도살체중 구 간 차이가 없었고, 가열육의 전단가는 성, 사료 및 도살체중 간의 상호작용 의 영향이 있어 $(\mathrm{P}<0.05)$ 해석상의 난점이 있었으나 실험 구 간 수치상의 차이는 크지 않았다. 수분 함량은 암퇘지 $(74.9 \%)$ 와 중에너지 구 $(75.0 \%)$ 가 각각 거세돼지 $(74.3 \%)$ 및 저에너지 구 $(74.2 \%)$ 보다 다소 높았고 $(\mathrm{P}<0.05)$, 조지방 함량은 역으로 저에너지 구 $(2.50 \%)$ 가 중에너지 구 $(2.04 \%)$ 보다 높았으나 $(\mathrm{P}<0.01)$ 거세돼지 $(2.31 \%)$ 와 암퇘지 $(2.24 \%)$ 간에는 차이가 없었다. 또한 본 변수는 중에너지 구에서 는 예상대로 $138 \mathrm{~kg}$ 도살체중 구 (2.24\%)가 $110 \mathrm{~kg}$ 구 $(1.74 \%)$ 보다 높았으나 $(\mathrm{P}<0.05)$ 저에너지 구에서는 다소 이례적으로 $125 \mathrm{~kg}$ 구 $(2.82 \%)$ 가 $138 \mathrm{~kg}$ 구 (2.18\%) 보다 높 았다 $(\mathrm{P}<0.05)$. 본 부위의 조단백질 함량은 성, 사료 혹은 도살체중과는 무관하였다.

등심의 명도는 삼겹살 근육층에서와 같이 저에너지 구 (55.6)가 중에너지 구 (52.1) 보다 높았고 $(\mathrm{P}<0.01)$, 중에너지 사료를 급여했을 때는 $110 \mathrm{~kg}$ 출하체중 구 (53.3)가 $138 \mathrm{~kg}$ 구(50.7) 보다 높은 경향을 나타냈으나 $(\mathrm{P}=0.06)$ 저에너지 사료를 급여한 경우에는 역으로 $138 \mathrm{~kg}$ 구 (56.8)가 $110 \mathrm{~kg}$ 구 $(54.5)$ 보다 높은 경향 $(\mathrm{P}=0.09)$ 을 나타내었다. 등심의 적 색도는 암퇘지 (8.36)가 거세돼지 (7.75) 보다 높았고 (P<
$0.05)$, 저에너지 구 (8.51)는 중에너지 구 (7.60) 보다 높았다 $(\mathrm{P}<0.01) . \mathrm{pH}$ 는 성, 사료 및 도살체중의 영향을 받지 않았 다. 보수력은 중에너지 구 (66.7)가 저에너지 구 (48.4)보다 컸고 $(\mathrm{P}<0.01)$, 육즙참출율은 암퇘지 $(1.95 \%)$ 가 거세돼지 $(1.36 \%)$ 보다 높았다 $(\mathrm{P}<0.05)$. 가열감량은 중에너지 구 $(34.6 \%)$ 보다 저에너지 구 $(36.3 \%)$ 에서 컸고 $(\mathrm{P}<0.01), 110 \mathrm{~kg}$ 출하체중 구 (36.3\%)와 $125 \mathrm{~kg}$ 구 $(35.5 \%)$ 간에는 차이가 없었으나 전자는 $138 \mathrm{~kg}$ 구 $(34.5 \%)$ 보다 높았다 $(\mathrm{P}<0.01)$. 가열육의 전단가는 저에너지 구 $\left(3.18 \mathrm{~kg} / \mathrm{cm}^{2}\right)$ 가 중에너지 구 $\left(2.83 \mathrm{~kg} / \mathrm{cm}^{2}\right)$ 보다 컸다. 수분 함량은 처리요인의 영향 을 받지 않았다. 조지방 함량은 거세돼지 $(2.77 \%)$ 가 암퇘 지 $(2.41 \%)$ 보다 높았고 $(\mathrm{P}<0.05)$, 중에너지 구 $(2.82 \%)$ 가 저 에너지 구 $(2.35 \%)$ 보다 높았다 $(\mathrm{P}<0.01)$. 또한 본 변수는 중에너지 사료를 급여했을 때는 도살체중 구 간 차이가 없었으나 $(110,125$ 및 $138 \mathrm{~kg}$ 도살체중 구: 각각 2.93 , 2.49 및 $3.05 \%$ ) 저에너지 사료 급여 시에는 도살체중이 $110 \mathrm{~kg}$ 으로부터 $125 \mathrm{~kg}$ 으로 증가될 때 다소 증가하였고 $(\mathrm{P}<0.05) 138 \mathrm{~kg}$ 으로 증가할 때는 더 이상 변하지 않았다 $(110,125$ 및 $138 \mathrm{~kg}$ 도살체중 구: 각각 $1.96,2.56$ 및 2.54\%). 조단백질 함량은 암퇘지에서는 중에너지 구 $(22.9 \%)$ 가 저에너지 구 $(22.1 \%)$ 보다 높았으나 $(\mathrm{P}<0.05)$, 거 세돼지에서는 두 사료 구 공히 $22.5 \%$ 로 차이가 없었고, 전체 공시돈의 도살체중 구 간에도 차이가 없었다 $(110$, 125 및 $138 \mathrm{~kg}$ 도살체중 구: 각각 22.3, 22.7 및 22.6\%).

\section{4. 관능평가}

삼겹살 근육층의 색깔은 중에너지 구 (5.87)가 저에너지 구 (5.57) 보다 다소 짙었고 $(\mathrm{P}<0.05), 110 \mathrm{~kg}(5.53)$ 과 $125 \mathrm{~kg}$ (5.68) 도살체중 구 간에는 차이가 없었으나 $138 \mathrm{~kg}$ 구 (5.94)는 전자보다 짙었다 $(\mathrm{P}<0.05$; Table 6). 삼겹살의 향은 저에너지 구 (4.31)가 중에너지 구 (3.10) 보다 강했다. 이상 취는 중에너지 구 (1.64)가 저에너지 구(0.85) 보다 높았고 $(\mathrm{P}<0.01)$, 거세돼지에서는 도살체중 구 간 차이가 없었으 나 암퇘지에서는 $110 \mathrm{~kg}$ 구 (1.87)가 $138 \mathrm{~kg}$ 구 (0.76) 보다 높았으며 $(\mathrm{P}<0.05)$, 중에너지 사료 급여 시에는 $138 \mathrm{~kg}$ 구 (1.00)가 $110 \mathrm{~kg}(1.96)$ 및 $125 \mathrm{~kg}(1.96)$ 구보다 낮았으나 $(\mathrm{P}<0.05)$ 저에너지 사료 급여 시는 도살체중 구 간 차이가 없었다. 본 부위의 근육층 대비 지방층의 비율은 거세돼 지 (5.74)가 암퇘지 (4.96) 보다 높았고 $(\mathrm{P}<0.01)$, 중에너지 구 (5.58)가 저에너지 구 (5.12) 보다 높았으며 $(\mathrm{P}<0.05)$, 도살체 중 $110 \mathrm{~kg}(4.87)$ 과 $125 \mathrm{~kg}(5.60)$ 사이 현저히 증가였으나 $(\mathrm{P}<0.01)$ 도살체중이 $138 \mathrm{~kg}(5.58)$ 으로 증가되었을 때는 더 이상 증가하지 않았다. 삼겹살 지방층:근육층의 균형은 거 세돼지에서는 도살체중 구 간 차이가 없었으나 암퇘지에 서는 도살체중이 $110 \mathrm{~kg}$ (4.82)에서 $125 \mathrm{~kg}$ (5.39)으로 증가 되면서 좋아졌고 $(\mathrm{P}<0.01) 138 \mathrm{~kg}(5.06)$ 으로 증가되었을 때 는 더 이상 변하지 않았다. 그러나 삼겹살 신선육의 전체 적인 기호도는 어느 처리요인에 의해서도 변하지 않았다.

뒷다리 신선육 색깔의 세기는 어느 처리요인에 의해서 
Table 5. Physicochemical characteristics of the belly, ham, and loin of the gilts and barrows

\begin{tabular}{|c|c|c|c|c|c|c|c|c|c|c|c|c|c|c|}
\hline \multirow{3}{*}{ Item } & \multicolumn{6}{|c|}{ Gilts } & \multicolumn{6}{|c|}{ Barrows } & \multirow{3}{*}{$\begin{array}{c}\text { Pooled } \\
\text { SE }\end{array}$} & \multirow{3}{*}{$\begin{array}{c}\text { Significance } \\
(\mathrm{S}, \mathrm{D}, \mathrm{SW})^{\mathrm{a}}, \\
*, * *\end{array}$} \\
\hline & \multicolumn{3}{|c|}{$3,200 \mathrm{kcal} \mathrm{DE} / \mathrm{kg}$} & \multicolumn{3}{|c|}{$3,000 \mathrm{kcal} \mathrm{DE} / \mathrm{kg}$} & \multicolumn{3}{|c|}{$3,200 \mathrm{kcal} \mathrm{DE} / \mathrm{kg}$} & \multicolumn{3}{|c|}{$3,000 \mathrm{kcal} \mathrm{DE} / \mathrm{kg}$} & & \\
\hline & $110 \mathrm{~kg}$ & $125 \mathrm{~kg}$ & $138 \mathrm{~kg}$ & $110 \mathrm{~kg}$ & $125 \mathrm{~kg}$ & $138 \mathrm{~kg}$ & $110 \mathrm{~kg}$ & $125 \mathrm{~kg}$ & $138 \mathrm{~kg}$ & $110 \mathrm{~kg}$ & $125 \mathrm{~kg}$ & $138 \mathrm{~kg}$ & & \\
\hline & & & & & & & & Belly & & & & & & \\
\hline CIE L*(muscle) & 49.8 & 49.9 & 48.5 & 54.0 & 53.6 & 54.4 & 50.1 & 49.2 & 48.4 & 54.3 & 55.6 & 58.7 & 1.2 & $\mathrm{D}^{* *}$ \\
\hline CIE L* (fat) & 78.0 & 78.4 & 78.4 & 79.6 & 78.9 & 78.4 & 78.5 & 79.2 & 78.5 & 80.3 & 80.2 & 80.6 & 0.5 & $\mathrm{~S}^{* *}, \mathrm{D}^{* *}$ \\
\hline CIE a* (muscle) & 11.3 & 12.7 & 12.0 & 11.4 & 12.6 & 10.8 & 11.6 & 11.2 & 12.8 & 11.7 & 11.3 & 11.1 & 0.6 & \\
\hline CIE b* (fat) & 4.36 & 3.64 & 3.78 & 4.81 & 5.12 & 4.96 & 4.05 & 4.63 & 3.66 & 4.61 & 5.35 & 4.52 & 0.40 & $\mathrm{D}^{* *}$ \\
\hline $24 \mathrm{~h} \mathrm{pH}$ (muscle) & 6.33 & 6.28 & 6.30 & 6.40 & 6.27 & 6.24 & 6.32 & 6.31 & 6.25 & 6.48 & 6.37 & 6.36 & 0.05 & $\mathrm{SW}^{*}$ \\
\hline Moisture, \% & 47.9 & 47.1 & 44.9 & 51.3 & 48.0 & 49.3 & 46.1 & 43.9 & 40.3 & 45.6 & 41.0 & 45.1 & 2.3 & $\mathrm{~S}^{* *}$ \\
\hline Crude fat, $\%$ & 34.7 & 35.4 & 36.6 & 30.3 & 34.1 & 36.0 & 35.7 & $\begin{array}{l}38.7 \\
\text { Ham }^{b}\end{array}$ & 41.7 & 37.3 & 40.0 & 39.1 & 3.0 & $\mathrm{~S}^{*}$ \\
\hline $\mathrm{L}^{*}$ & 43.2 & 44.6 & 44.2 & 47.0 & 46.2 & 47.1 & 48.2 & $4 \overline{5.1}$ & 47.9 & 46.1 & 45.9 & 45.9 & 1.6 & $\mathrm{~S} \times \mathrm{D}^{*}$ \\
\hline$a^{*}$ & 9.8 & 10.7 & 10.7 & 10.4 & 10.6 & 10.5 & 10.2 & 10.6 & 10.9 & 10.4 & 10.6 & 9.9 & 0.5 & \\
\hline $24 \mathrm{~h} \mathrm{pH}$ & 5.87 & 5.69 & 5.81 & 5.65 & 5.63 & 5.65 & 5.91 & 5.85 & 5.68 & 5.69 & 5.75 & 5.80 & 0.08 & $\mathrm{D}^{*}$ \\
\hline Water holding cap., \% & 57.0 & 57.0 & 55.5 & 59.5 & 55.0 & 58.0 & 54.0 & 59.8 & 54.8 & 58.2 & 54.7 & 58.4 & 2.6 & \\
\hline Drip loss, $\%$ & 0.86 & 1.42 & 1.16 & 1.93 & 1.97 & 1.31 & 1.36 & 1.73 & 1.66 & 0.91 & 0.79 & 0.69 & 0.35 & $\mathrm{~S} \times \mathrm{D}^{* *}$ \\
\hline Cooking loss, \% & 38.8 & 39.9 & 38.3 & 40.1 & 39.7 & 38.3 & 40.1 & 39.6 & 39.9 & 38.8 & 38.2 & 39.6 & 0.8 & \\
\hline Shear force $\mathrm{c}^{\mathrm{c}}, \mathrm{kg} / \mathrm{cm}^{2}$ & 4.40 & 5.32 & 4.09 & 4.50 & 3.69 & 4.47 & 3.85 & 3.93 & 5.03 & 4.69 & 4.13 & 4.19 & 0.42 & $\mathrm{~S} \times \mathrm{D} \times \mathrm{SW} *$ \\
\hline Moisture, \% & 75.8 & 75.3 & 74.7 & 74.8 & 74.4 & 74.6 & 74.7 & 75.2 & 74.2 & 74.4 & 73.5 & 73.6 & 0.5 & $\mathrm{~S}^{*}, \mathrm{D}^{*}$ \\
\hline Crude fat, $\%$ & 1.83 & 2.08 & 1.98 & 2.38 & 3.00 & 2.15 & 1.64 & 2.24 & 2.50 & 2.61 & 2.65 & 2.23 & 0.24 & $\mathrm{D}^{* *}, \mathrm{D} \times \mathrm{SW}^{*}$ \\
\hline Crude protein, $\%$ & 20.9 & 21.3 & 21.8 & 21.3 & 21.5 & 21.9 & 22.0 & $\begin{array}{l}21.0 \\
\text { Loin }^{\mathrm{b}}\end{array}$ & 22.0 & 21.6 & 22.3 & 22.0 & 0.5 & \\
\hline CIE L* & 53.4 & 52.9 & 49.3 & 54.7 & 54.6 & 56.9 & 53.2 & 52.0 & 52.0 & 54.3 & 56.1 & 56.8 & 1.4 & $\mathrm{D}^{* *}, \mathrm{D} \times \mathrm{SW}^{*}$ \\
\hline CIE $a^{*}$ & 7.8 & 7.8 & 7.3 & 9.1 & 9.8 & 8.4 & 7.2 & 7.3 & 8.2 & 7.9 & 8.6 & 7.2 & 0.5 & $\mathrm{~S}^{*}, \mathrm{D}^{* *}$ \\
\hline $24 \mathrm{~h} \mathrm{pH}$ & 5.65 & 5.54 & 5.72 & 5.58 & 5.63 & 5.64 & 5.71 & 5.59 & 5.61 & 5.64 & 5.61 & 5.70 & 0.06 & \\
\hline Water holding cap., \% & 63.8 & 59.7 & 66.9 & 47.8 & 50.1 & 47.8 & 70.8 & 70.0 & 69.1 & 45.8 & 50.0 & 48.7 & 2.7 & $\mathrm{D}^{* *}$ \\
\hline Drip loss, \% & 2.10 & 2.17 & 1.42 & 2.16 & 1.54 & 2.34 & 1.98 & 1.45 & 1.68 & 1.15 & 1.22 & 0.70 & 0.48 & $\mathrm{~S}^{*}$ \\
\hline Cooking loss, \% & 35.1 & 34.6 & 33.4 & 37.1 & 36.3 & 36.0 & 36.6 & 35.0 & 33.0 & 36.4 & 36.2 & 35.7 & 0.9 & $\mathrm{D}^{* *}, \mathrm{SW}^{*}$ \\
\hline Shear force $\mathrm{e}^{\mathrm{c},} \mathrm{kg} / \mathrm{cm}^{2}$ & 2.99 & 2.87 & 3.07 & 3.57 & 2.98 & 2.93 & 2.65 & 2.70 & 2.69 & 3.28 & 2.95 & 3.39 & 0.28 & $D^{*}$ \\
\hline Moisture, \% & 74.2 & 73.5 & 73.9 & 73.9 & 73.9 & 73.9 & 74.0 & 73.7 & 72.3 & 74.2 & 73.4 & 73.6 & 0.4 & \\
\hline Crude fat, \% & 2.91 & 2.46 & 2.60 & 1.85 & 2.42 & 2.22 & 2.95 & 2.53 & 3.50 & 2.07 & 2.70 & 2.86 & 0.27 & $\mathrm{~S}^{*}, \mathrm{D}^{* *}, \mathrm{D} \times \mathrm{SW}^{*}$ \\
\hline Crude protein, \% & 22.7 & 23.1 & 22.8 & 22.2 & 21.9 & 22.3 & 22.1 & 22.6 & 22.7 & 22.2 & 23.0 & 22.4 & 0.3 & $\mathrm{~S} \times \mathrm{D}^{*}$ \\
\hline
\end{tabular}

${ }^{a} \mathrm{~S}$, sex; D, diet; SW, slaughter weight.

${ }^{b}$ Data are means of six animals in each $\mathrm{S} \times \mathrm{D} \times \mathrm{SW}$ combination.

${ }^{c}$ Measured on cooked meat.

* $\mathrm{P}<0.05$.

** $\mathrm{P}<0.01$ 
Table 6. Sensory quality traits of the fresh belly, ham, and loin of the gilts and barrows

\begin{tabular}{|c|c|c|c|c|c|c|c|c|c|c|c|c|c|c|}
\hline \multirow{3}{*}{ Item } & \multicolumn{6}{|c|}{ Gilts } & \multicolumn{6}{|c|}{ Barrows } & \multirow{3}{*}{$\begin{array}{c}\text { Pooled } \\
\text { SE }\end{array}$} & \multirow{3}{*}{$\begin{array}{c}\text { Significance } \\
(\mathrm{S}, \mathrm{D}, \mathrm{SW})^{\mathrm{a}} \\
*, * *\end{array}$} \\
\hline & \multicolumn{3}{|c|}{$3,200 \mathrm{kcal} \mathrm{DE} / \mathrm{kg}$} & \multicolumn{3}{|c|}{$3,000 \mathrm{kcal} \mathrm{DE} / \mathrm{kg}$} & \multicolumn{3}{|c|}{$3,200 \mathrm{kcal} \mathrm{DE} / \mathrm{kg}$} & \multicolumn{3}{|c|}{$3,000 \mathrm{kcal} \mathrm{DE} / \mathrm{kg}$} & & \\
\hline & $110 \mathrm{~kg}$ & $125 \mathrm{~kg}$ & $138 \mathrm{~kg}$ & $110 \mathrm{~kg}$ & $125 \mathrm{~kg}$ & $138 \mathrm{~kg}$ & $110 \mathrm{~kg}$ & $125 \mathrm{~kg}$ & $138 \mathrm{~kg}$ & $110 \mathrm{~kg}$ & $125 \mathrm{~kg}$ & $138 \mathrm{~kg}$ & & \\
\hline & \multicolumn{14}{|c|}{ Belly $^{b}$} \\
\hline Color $(\text { fat })^{\mathrm{c}}$ & 5.19 & 4.83 & 5.24 & 5.29 & 4.93 & 5.29 & 5.21 & 5.36 & 5.00 & 5.43 & 5.52 & 5.64 & 0.25 & \\
\hline Color $\left(\right.$ muscle) ${ }^{\mathrm{c}}$ & 5.62 & 5.79 & 6.10 & 5.14 & 5.60 & 5.71 & 5.60 & 5.76 & 6.33 & 5.76 & 5.57 & 5.62 & 0.23 & $\mathrm{D}^{*}, \mathrm{SW}^{*}$ \\
\hline Aroma $^{c}$ & 2.98 & 3.05 & 3.02 & 4.10 & 4.38 & 4.45 & 3.14 & 3.24 & 3.17 & 4.33 & 4.21 & 4.41 & 0.15 & $\mathrm{D}^{* *}$ \\
\hline Off-flavor $^{\mathrm{d}}$ & 3.00 & 2.00 & 0.69 & 0.74 & 0.62 & 0.83 & 0.93 & 1.93 & 1.31 & 0.62 & 0.76 & 1.52 & 0.45 & $\mathrm{D}^{* *}, \mathrm{~S} \times \mathrm{SW}^{*}, \mathrm{D} \times \mathrm{SW}^{*}$ \\
\hline Fat:lean ratio ${ }^{c}$ & 5.19 & 5.38 & 5.33 & 4.02 & 4.64 & 5.19 & 5.02 & 6.29 & 6.24 & 5.24 & 6.07 & 5.57 & 0.34 & $\mathrm{~S}^{* *}, \mathrm{D}^{*}, \mathrm{SW}^{* *}$ \\
\hline Fat:lean balance ${ }^{c}$ & 5.26 & 4.48 & 4.79 & 4.38 & 5.31 & 5.33 & 5.24 & 4.76 & 4.86 & 5.10 & 5.24 & 5.24 & 0.21 & $\mathrm{~S} \times \mathrm{SW}^{*}, \mathrm{D} \times \mathrm{SW}^{* *}$ \\
\hline \multirow[t]{2}{*}{ Acceptability $^{\mathrm{c}}$} & 5.33 & 5.52 & 5.19 & 4.67 & 5.62 & 5.50 & 5.21 & 5.12 & 5.36 & 5.14 & 5.24 & 5.48 & 0.23 & \\
\hline & \multicolumn{14}{|c|}{$\underline{\operatorname{Ham}}^{\mathrm{b}}$} \\
\hline Color & 6.08 & 5.58 & 6.56 & 5.38 & 5.35 & 5.27 & 5.27 & 6.05 & 5.50 & 5.38 & 5.71 & 5.57 & 0.42 & \\
\hline Aroma & 3.64 & 3.70 & 3.65 & 4.37 & 4.76 & 4.76 & 3.56 & 3.73 & 3.58 & 4.56 & 4.73 & 4.40 & 0.15 & $\mathrm{D}^{* *}$ \\
\hline Off-flavor & 2.94 & 3.18 & 3.15 & 4.08 & 4.11 & 4.17 & 3.27 & 3.18 & 3.16 & 4.25 & 3.97 & 4.00 & 0.15 & $\mathrm{D}^{* *}$ \\
\hline Drip $^{d}$ & 4.98 & 5.83 & 5.82 & 5.67 & 6.09 & 5.67 & 5.26 & 5.48 & 5.97 & 5.73 & 5.42 & 4.98 & 0.30 & $\mathrm{D} \times \mathrm{SW}^{*}$ \\
\hline Marbling $^{\mathrm{c}}$ & 3.45 & 3.65 & 3.67 & 4.77 & 5.39 & 4.52 & 4.14 & 4.44 & 4.40 & 4.77 & 5.25 & 5.50 & 0.34 & $\mathrm{~S}^{*}, \mathrm{D}^{* *}$ \\
\hline \multirow[t]{2}{*}{ Acceptability } & 4.89 & 4.91 & 5.27 & 5.33 & 5.61 & 5.22 & 5.11 & 5.32 & 5.24 & 5.47 & 5.44 & 5.55 & 0.21 & $\mathrm{D}^{*}$ \\
\hline & \multicolumn{14}{|c|}{$\underline{\text { Loin }}^{\mathbf{b}}$} \\
\hline Color & 5.96 & 6.03 & 6.56 & 5.23 & 5.84 & 4.65 & 5.58 & 6.50 & 6.35 & 5.46 & 5.13 & 4.56 & 0.33 & $\mathrm{D}^{* *}, \mathrm{D} \times \mathrm{SW}^{* *}$ \\
\hline Aroma & 2.60 & 2.51 & 2.68 & 3.69 & 3.67 & 3.57 & 2.72 & 2.71 & 2.61 & 3.74 & 3.67 & 3.36 & 0.14 & $\mathrm{D}^{* *}$ \\
\hline Off-flavor & 2.53 & 2.36 & 2.38 & 2.54 & 2.35 & 2.21 & 2.57 & 2.43 & 2.43 & 2.35 & 2.23 & 2.40 & 0.10 & $\mathrm{SW}^{*}$ \\
\hline Drip & 5.40 & 5.32 & 5.43 & 4.83 & 5.07 & 5.07 & 5.32 & 5.53 & 5.39 & 5.50 & 4.26 & 4.55 & 0.28 & $\mathrm{D}^{* *}$ \\
\hline Marbling & 3.25 & 4.93 & 4.90 & 4.16 & 4.54 & 4.49 & 4.17 & 4.56 & 5.46 & 4.44 & 5.59 & 5.11 & 0.51 & $\mathrm{SW}^{*}$ \\
\hline Acceptability & 5.10 & 5.63 & 5.79 & 4.88 & 5.09 & 4.81 & 5.38 & 5.78 & 5.88 & 5.09 & 5.12 & 5.05 & 0.23 & $\mathrm{D}^{* *}$ \\
\hline
\end{tabular}

a , sex; D, diet; SW, slaughter weight.

${ }^{b}$ Data are means of six animals in each $\mathrm{S} \times \mathrm{D} \times \mathrm{SW}$ combination.

${ }^{c, d}$ Evaluated by seven to twelve sensory panelists according to a 9-point hedonic scale.

" Greater values indicate "darker," "stronger," "superior," and "greater" in color, aroma, fat:lean balance/acceptability, and fat:lean ratio/marbling, respectively.

d Greater values indicate "more" meaning "worse" in terms of quality.

* $\mathrm{P}<0.05$. ** $\mathrm{P}<0.01$. 
Table 7. Sensory quality traits of the cooked belly, ham and loin of the gilts and barrows

\begin{tabular}{|c|c|c|c|c|c|c|c|c|c|c|c|c|c|c|}
\hline \multirow{3}{*}{ Item } & \multicolumn{6}{|c|}{ Gilts } & \multicolumn{6}{|c|}{ Barrows } & \multirow{3}{*}{$\begin{array}{c}\text { Pooled } \\
\text { SE }\end{array}$} & \multirow{3}{*}{$\begin{array}{c}\text { Significance } \\
(\mathrm{S}, \mathrm{D}, \mathrm{SW})^{\mathrm{a}} \\
*, * *\end{array}$} \\
\hline & \multicolumn{3}{|c|}{$3,200 \mathrm{kcal} \mathrm{DE} / \mathrm{kg}$} & \multicolumn{3}{|c|}{$3,000 \mathrm{kcal} \mathrm{DE} / \mathrm{kg}$} & \multicolumn{3}{|c|}{$3,200 \mathrm{kcal} \mathrm{DE} / \mathrm{kg}$} & \multicolumn{3}{|c|}{$3,000 \mathrm{kcal} \mathrm{DE} / \mathrm{kg}$} & & \\
\hline & $110 \mathrm{~kg}$ & $125 \mathrm{~kg}$ & $138 \mathrm{~kg}$ & $110 \mathrm{~kg}$ & $125 \mathrm{~kg}$ & $138 \mathrm{~kg}$ & $110 \mathrm{~kg}$ & $125 \mathrm{~kg}$ & $138 \mathrm{~kg}$ & $110 \mathrm{~kg}$ & $125 \mathrm{~kg}$ & $138 \mathrm{~kg}$ & & \\
\hline & \multicolumn{14}{|c|}{ Belly $^{b}$} \\
\hline Aroma $^{c}$ & 4.36 & 4.36 & 4.12 & 5.00 & 4.77 & 5.44 & 4.48 & 4.41 & 4.36 & 4.79 & 5.02 & 4.96 & 0.18 & $\mathrm{D}^{* *}$ \\
\hline Off-flavor $^{\mathrm{d}}$ & 2.87 & 2.54 & 2.68 & 2.06 & 2.42 & 2.35 & 2.80 & 2.80 & 2.77 & 2.17 & 2.23 & 2.25 & 0.13 & $\mathrm{D}^{* *}$ \\
\hline Juiciness $^{\mathrm{c}}$ & 5.32 & 5.58 & 5.53 & 5.54 & 5.17 & 5.44 & 5.55 & 5.53 & 5.67 & 5.48 & 5.40 & 5.40 & 0.16 & \\
\hline Tenderness $^{c}$ & 5.44 & 5.63 & 5.82 & 5.56 & 5.71 & 5.60 & 5.25 & 5.51 & 5.44 & 6.00 & 6.21 & 5.58 & 0.22 & $\mathrm{D}^{*}, \mathrm{~S} \times \mathrm{D}^{*}$ \\
\hline Taste $^{c}$ & 5.75 & 5.68 & 5.63 & 5.96 & 5.63 & 5.98 & 5.51 & 5.39 & 5.82 & 5.71 & 6.00 & 5.88 & 0.19 & \\
\hline \multirow[t]{2}{*}{ Acceptability ${ }^{\mathrm{c}}$} & 5.25 & 5.44 & 5.47 & 5.75 & 5.63 & 5.77 & 5.47 & 5.30 & 5.44 & 5.73 & 5.96 & 5.63 & 0.18 & $\mathrm{D}^{* *}$ \\
\hline & \multicolumn{14}{|c|}{$\underline{\mathbf{H a m}}^{\mathrm{b}}$} \\
\hline Color & 5.35 & 5.70 & 5.17 & 5.51 & 6.04 & 5.54 & 5.20 & 5.50 & 5.58 & 5.64 & 5.77 & 5.54 & 0.21 & \\
\hline Aroma & 4.48 & 4.73 & 4.78 & 6.03 & 5.73 & 5.97 & 4.73 & 4.97 & 4.70 & 6.03 & 5.83 & 6.03 & 0.18 & $\mathrm{D}^{* *}$ \\
\hline Off-flavor & 3.68 & 3.72 & 3.83 & 4.18 & 4.38 & 4.55 & 3.63 & 4.03 & 3.62 & 4.38 & 4.21 & 4.18 & 0.18 & $\mathrm{D}^{* *}$ \\
\hline Juiciness & 5.03 & 4.85 & 4.90 & 5.16 & 5.26 & 5.26 & 4.90 & 4.80 & 4.90 & 5.40 & 5.70 & 5.60 & 0.25 & $\mathrm{D}^{* *}$ \\
\hline Tenderness & 4.82 & 4.92 & 5.00 & 5.14 & 5.17 & 4.81 & 5.17 & 4.70 & 4.43 & 5.11 & 5.67 & 5.27 & 0.29 & \\
\hline \multirow[t]{2}{*}{ Acceptability } & 4.95 & 4.90 & 5.02 & 5.26 & 5.09 & 4.89 & 5.20 & 4.85 & 4.68 & 5.19 & 5.56 & 5.29 & 0.20 & $\mathrm{D}^{*}$ \\
\hline & \multicolumn{14}{|c|}{$\underline{\text { Loin }}^{b}$} \\
\hline Color & 5.28 & 5.27 & 5.33 & 4.99 & 5.05 & 4.82 & 5.08 & 5.10 & 5.32 & 4.89 & 4.99 & 5.09 & 0.21 & \\
\hline Aroma & 4.03 & 3.88 & 3.93 & 3.04 & 3.31 & 3.51 & 4.13 & 4.05 & 4.07 & 3.24 & 3.27 & 3.31 & 0.15 & $\mathrm{D}^{* *}$ \\
\hline Off-flavor & 3.43 & 3.45 & 3.23 & 1.98 & 2.01 & 2.25 & 3.20 & 3.33 & 3.43 & 1.88 & 2.01 & 2.25 & 0.13 & $\mathrm{D}^{* *}$ \\
\hline Juiciness & 4.80 & 4.78 & 4.65 & 4.09 & 3.86 & 3.93 & 4.37 & 4.42 & 4.72 & 3.96 & 4.36 & 4.16 & 0.27 & $\mathrm{D}^{* *}$ \\
\hline Tenderness & 5.08 & 5.33 & 4.70 & 4.84 & 4.78 & 5.04 & 5.17 & 4.93 & 5.27 & 5.11 & 5.48 & 5.24 & 0.32 & \\
\hline Acceptability & 5.35 & 5.52 & 5.08 & 4.98 & 5.18 & 5.01 & 5.32 & 5.13 & 5.22 & 5.32 & 5.48 & 5.48 & 0.23 & \\
\hline
\end{tabular}

${ }^{a}$ S, sex; D, diet; SW, slaughter weight.

${ }^{\mathrm{b}}$ Data are means of six animals in each $\mathrm{S} \times \mathrm{D} \times \mathrm{SW}$ combination.

${ }^{\mathrm{c}, \mathrm{d}}$ Evaluated by seven to twelve sensory panelists according to a 9-point hedonic scale

Greater values indicate "darker," "stronger," and "more/superior" in color, aroma, and juiciness/tenderness/taste/acceptability, respectively.

d Greater values indicate "more" meaning "worse" in terms of quality.

$* \mathrm{P}<0.05$.

** $\mathrm{P}<0.01$. 
도 영향을 받지 않았고, 향은 저에너지 구(5.60)가 중에너 지 구 (3.64)보다 강했으며, 이상취 역시 저에너지 구 (4.10) 가 중에너지 구 (3.14) 보다 강했다. 육즙참출 정도 (drip)는 중에너지 구에서는 도살체중 $110 \mathrm{~kg}(5.12)$ 과 $125 \mathrm{~kg}(5.66)$ 사이 증가하였으나 $138 \mathrm{~kg}$ (5.89)에서는 더 이상 변하지 않 았고, 저에너지 구에서는 도살체중과 무관하였다. 본 부위 의 상강도는 거세돼지 (4.76)가 암퇘지 (4.24) 보다 높았고 $(\mathrm{P}<0.05)$, 저에너지 구 $(5.03)$ 가 중에너지 구 (3.96) 보다 현 저히 높았으며 $(\mathrm{P}<0.01)$, 도살체중 $110 \mathrm{~kg}(4.29)$ 과 $125 \mathrm{~kg}$ (4.68) 사이에서 증가하는 경향 $(\mathrm{P}=0.10)$ 이 있었으나 도살체 중이 $138 \mathrm{~kg}$ (4.53)으로 증가될 때는 더 이상의 경향이 나 타나지 않았다. 전체적인 기호도에 있어서도 저에너지 구 (5.44)가 중에너지 구 (5.12) 보다 높았다 $(\mathrm{P}<0.05)$.

등심 신선육 색깔은 삼겹살에서와 같이 중에너지 구 (6.16)가 저에너지 구 $(5.15)$ 보다 짙었고 $(\mathrm{P}<0.01)$, 중에너지 구에서는 $138 \mathrm{~kg}$ 출하체중 구가 $110 \mathrm{~kg}$ 구보다 짙었으나 $(\mathrm{P}<0.05 ; 110,125$ 및 $138 \mathrm{~kg}$ 출하체중 구: 각각 $5.77,6.26$ 및 6.45) 저에너지 구에서는 $125 \mathrm{~kg}$ 구가 $138 \mathrm{~kg}$ 구보다 짙 었다 $(\mathrm{P}<0.05 ; 110,125$ 및 $138 \mathrm{~kg}$ 출하체중 구: 각각 5.34, 5.49 및 4.61). 향은 삼겹살 및 뒷다리에서와 같이 저에너 지 구 (3.62)가 중에너지 구 (2.64) 보다 강했다 $(\mathrm{P}<0.01)$. 이 상취는 도살체중 $125 \mathrm{~kg}$ (2.36) 및 $138 \mathrm{~kg}(2.35)$ 구가 $110 \mathrm{~kg}$ (2.50) 구보다 덜했으나 $(\mathrm{P}<0.05)$ 수치상의 차이는 크지 않 았고, 육즙참출 정도는 저에너지 구 (4.88)가 중에너지 구 (5.40) 보다 낮았다 $(\mathrm{P}<0.01)$. 상강도는 도살체중 $110 \mathrm{~kg}$ (4.01)과 $125 \mathrm{~kg}(4.90)$ 사이 증가하였으나 $(\mathrm{P}<0.05)$ 도살체중 $125 \mathrm{~kg}$ 과 $138 \mathrm{~kg}$ (4.99) 사이에서는 더 이상 증가하지 않았 다. 등심에 대한 기호도는 뒷다리에서의 결과와는 대조적 으로 중에너지 구(5.59)가 저에너지 구 (5.01) 보다 높았다 $(\mathrm{P}<0.01)$.

삼겹살 가열육의 향은 저에너지 구 (5.00)가 중에너지 구 (4.35) 보다 강하였고 $(\mathrm{P}<0.01)$, 이상취는 중에너지 구 (2.74) 가 저에너지 구 $(2.25)$ 보다 높았다 $(\mathrm{P}<0.01)$. 다즙성은 처리 요인의 영향을 받지 않았고, 연도는 저에너지 구 (5.78)가 중에너지 구 $(5.52)$ 보다 약간 높았으며 $(\mathrm{P}<0.05)$, 거세돼지 에서는 저에너지 구 (5.93)가 중에너지 구 (5.41) 보다 높았 으나 $(\mathrm{P}<0.01)$ 암퇘지에서는 두 에너지수준 구 간 차이가 없었다. 맛은 처리요인과는 무관하였으나 기호도는 저에 너지 구 (5.74)가 중에너지 구 (5.39) 보다 좋았다 $(\mathrm{P}<0.01)$.

뒷다리 가열육의 색깔의 세기와 연도는 처리요인의 효과 가 없었으나, 향의 세기, 이상취, 다즙성 (각각 $\mathrm{P}<0.01)$ 및 기 호도 $(\mathrm{P}<0.05)$ 는 저에너지 구가 중에너지 구보다 높았다 (각 각 5.94 vs $4.73 ; 4.31$ vs $3.75 ; 5.40$ vs $4.90 ; 5.21$ vs 4.93$)$.

뒷다리에서의 결과와는 다소 대조적으로 등심 가열육에 서는 중에너지 구가 저에너지 구보다 향의 세기 (4.02 vs $3.28)$, 이상취 (3.47 vs 2.07) 및 다즙성 (4.62 vs 4.06) 수치 가 높았고 $(\mathrm{P}<0.01)$, 색깔, 연도 및 기호도는 처리요인의 영향이 없었다.

\section{IV. 고 찰}

본 실험의 결과 일당증체량은 선행연구(박 등, 2009)에 서와 같이 체중이 $110 \mathrm{~kg}$ 에서 $125 \mathrm{~kg}$ 으로 증가하면서 동반 증가하였고 증가된 일당증체량은 체중 $138 \mathrm{~kg}$ 까지 지속되 었다. 본 공시돈의 일당사료섭취량은 $110 \mathrm{~kg}$ 이후 증가하 였으나 사료효율은 생체중과 무관하게 일정수준이 유지되 어 본 연구에 쓰인 돈군의 비육후기 적육 축적 능력이 우 수하다는 것을 본 사양시험의 성장성적으로부터 알 수 있 다. 본 연구에 쓰인 중에너지 $(3.2 \mathrm{Mcal} \mathrm{DE} / \mathrm{kg}$ ) 대비 저에 너지 $(3.0 \mathrm{Mcal})$ 사료가 사료효율과 일당증체량에 미친 영 향은 선행연구 (Lee 등, 2002)에서 시도되었던 $3.5 \mathrm{Mcal}$ 대 비 $2.95 \mathrm{Mcal} \mathrm{DE} / \mathrm{kg}$ 의 상대적인 효과에서와 같이 전자보다 효과가 낮았다. 이는 $3.4 \mathrm{Mcal}$ 대비 $3.2 \mathrm{Mcal} \mathrm{DE} / \mathrm{kg}$ 의 비육 돈사료는 증체량, 사료섭취량 및 사료효율에서 전자와 차 이가 없었던 선행연구(이 등, 2007)의 결과와는 대조적인 결과로서 본 연구에 쓰인 저에너지 사료는 비육돈의 총에 너지 섭취량과 증체량을 제한하는 효과가 있음을 시사한 다. 본 연구에서 밝혀진 가장 놀라운 결과는 생체중 110 $\mathrm{kg}$ 과 $138 \mathrm{~kg}$ 사이에서 도체의 육질등급이 생체중과는 전 혀 관계가 없었다는 사실이었다. 반면 육량등급은 선행연구 (이 등, 2006, 2007; 박 등, 2007)의 결과에서와 같이 생체중 $110 \mathrm{~kg}$ 과 $125 \mathrm{~kg}$ 사이에서는 크게 변하지 않았으나, $125 \mathrm{~kg}$ 이후에서는 '과중량' 도체가 산출되어 급격히 저하되었다.

정육율은 선행연구 (박 등, 2007, 2009)에서와 같이 암퇘 지가 거세돼지보다 높았는데 이는 전자가 후자에서보다 정형시 지방으로 제거되는 비율이 작기 때문이고, 본 변 수는 또한 다소간의 성 $\times$ 도살체중의 상호작용의 영향을 받았으나 수치상으로는 의미를 부여할만한 수준은 아니었 다. 총 정육 중량 대비 각각 부분육 중량의 비율은 부분 육 종류에 따라 성, 사료, 도살체중, 혹은 이들 간의 상호 작용의 영향이 있었으나 수치상으로는 큰 의미를 부여할 만한 수준은 아니었고, 다만 경제적으로 가장 중요한 삼 겹살의 비율이 기 보고된 결과(이 등, 2006, 박 등, 2007)에 서와 같이 거세돼지가 암퇘지보다 높았고, 생체중 $110 \mathrm{~kg}$ 대비 $125 \sim 138 \mathrm{~kg}$ 비육돈이 높았던 결과는 주목할 만하다.

삼겹살, 뒷다리 및 등심 부위의 이화학적 특성은 변수 에 따라 성, 사료, 도살체중, 혹은 이들 요인 간 상호작용 의 영향이 있었으나 전체적으로 이들 요인 효과의 크기는 주목할 만한 수준은 아니었고 모든 실험구에서 정상적인 측정치를 나타내었다. 그러나 뒷다리의 조지방 함량과 등 심의 적색도 및 전단가에서 저에너지사료 구가 중에너지 사료 구보다 높았던 결과는 Latorre 등 (2004)의 보고와도 일치하는 결과로서 전자가 후자보다 성장률이 낮아 도살 일령이 증가하고 이와 동반하여 지방침착, 근육의 myoglobin 함량 및 결체조직 함량이 증가했기 때문이었던 것 으로 추측된다. 반면 이와는 다소 이율배반적으로 뒷다리 와 등심의 적색도는 도살체중의 영향을 받지 않았는데 이 는 선행연구(박 등, 2007)의 결과에서와 같이 본 연구에 쓰인 공시돈의 수가 작아 도살체중 증가에 따른 등심의 
적색도 증가가 개체변이에 의해 가려졌을 가능성이 있었 음을 시사한다. 뒷다리와 등심의 지방함량 또한 출하체중 과 무관하였는데 이는 도살체중 $137 \mathrm{~kg}$ 까지는 도살체중이 등심의 지방함량에 영향을 미치지 않았던 Martin 등 (1980) 과 Monin 등 (1999)의 결과와도 일치하였다. 그러나 도살 체중 $110 \mathrm{~kg}$ 과 $160 \mathrm{~kg}$ 사이에서는 도살체중과 등심의 지방 함량 간에 정의 상관관계가 있었다는 보고 (Cisneros 등, 1996)를 감안하면 전자의 연구와 본 연구에서의 도살체중 범위가 부분육의 지방 함량에 영향을 미치기에는 너무 좁 았던 것으로 해석된다. 한편 등심 부위의 조단백질 함량 은 박 등 $(2007,2009)$ 의 선행연구 결과에서와는 달리 본 연구와 이 등 (2006)의 연구결과에서는 $110 \mathrm{~kg}$ 비육돈에 비 해 $125 \sim 135 \mathrm{~kg}$ 고체중 비육돈이 높지 않았다. 따라서 본 부위는 시료를 준비할 때 분석시료로 채취되는 지방조직 과 근육조직의 비율에 다소간의 '치우침'이 발생할 수 있 기 때문에 조단백질 분석결과 또한 다소간 과장될 수 있 을 것으로 추측된다.

삼겹살, 뒷다리 및 등심 신선육에 대한 관능평가 결과 는 다수의 처리요인 혹은 요인 간 상호작용의 효과가 검 출되었고 이중에는 선행연구 (박 등, 2009)의 결과와 일치 하지 않는 경우도 있었으나 전체적으로 다음의 경우 외에 는 크게 주목할만한 수준은 아니었던 것으로 사료된다. 경제적으로 가장 중요한 부위인 삼겹살의 지방층:근육층 비율/균형은 도살체중 구 간에는 유의차 없이 암퇘지에서 만 $110 \mathrm{~kg}$ 과 $125 \mathrm{~kg}$ 사이 증가하였는데 이는 성에 관계 없 이 $125 \mathrm{~kg}$ 도살체중 구가 110 및 $135 \mathrm{~kg}$ 구보다 높았던 선 행연구 (박 등, 2009)의 결과와는 다소간의 차이는 있었으 나, 본 부위에 대한 기호도는 두 연구에서 공히 성 및 도 살체중과는 무관하였다. 뒷다리와 등심 신선육의 상강도 는 선행연구 (박 등, 2009)에서와 같이 도살체중 $110 \mathrm{~kg}$ 이 후 증가 혹은 증가하는 경향이 검출되어 $110 \mathrm{~kg}$ 출하 대 비 $125 \mathrm{~kg}$ 이상 고체중 출하의 잇점을 보여주었다. 한편 신선육과 가열육 관능평가에서 다수의 사료, 사료 $\times$ 성, 혹 은 사료 $\times$ 도살체중 간 상호작용의 효과가 검출되기는 하 였으나 부위 간 효과가 일치하지 않는 경우도 검출되었기 때문에 본 연구의 결과만으로는 사료의 에너지수준의 효 과를 단정짓기에는 무리가 있을 것으로 사료된다.

본 연구결과와 2008년 말의 등급별 도체가, 사료를 제 외한 2 (성) $\times 3$ (도살체중) 요인분석 모델 하에서의 생산성 적 및 저에너지사료 및 중에너지사료의 평균 사료가 $(500$ 원 $/ \mathrm{kg}$ )를 기준으로 $110 \mathrm{~kg}$ 출하 대비 125 혹은 $138 \mathrm{~kg}$ '고 체중' 출하의 수익성을 계산하면 암퇘지에서는 두당 각각 약 3,700 원 및 $-12,600$ 원, 거세돼지에서는 약 12,000 원 및 1,000 원의 한계수익이 추산되었다 (본 자료는 Table에 없 음). 이 중 거세돼지에서는 본 연구에서의 성장성적이 예 외적으로 좋았기 때문에 고체중 출하의 한계수익이 평균 적인 상황에서보다는 다소간 크게 계산되었을 것으로 추 측되는 바 전체적으로 $110 \mathrm{~kg}$ 대비 $125 \mathrm{~kg}$ 출하는 전자에 비해 유리하나 $138 \mathrm{~kg}$ 출하는 암퇘지와 거세돼지 공히 불 리할 것으로 예측된다. 그러나 만일 고체중 출하돈 도체
에 현행 육량등급을 적용하지 않고 이들의 육질등급 분포 가 $110 \mathrm{~kg}$ 출하돈과 같다는 전제하에서 계산하면 $110 \mathrm{~kg}$ 대비 125 및 $138 \mathrm{~kg}$ 출하의 두당 한계수익은 암퇘지에서 는 각각 약 4,900 원 및 30,600 원, 거세돼지에서는 약 18,400 원 및 35,300 원에 이를 것으로 추산되었다. 이와 같 은 추산치는 전체적으로 육량등급만이 적용되었던 선행연 구 (이 등, 2006; 박 등, 2007)에서 제시되었던 성별 고체중 비육돈의 한계수익 추정치와 유사하였다. 따라서 본 연구 결과는 육량등급이 육질을 충분히 반영할 수 없었기 때문 에 도입되었던 육질등급제 (농림부, 2007) 적용에 대한 당 초의 기대와는 달리 생체중 약 $125 \mathrm{~kg}$ 이상에서는 중량이 증가할수록 $\mathrm{kg}$ 당 도체가격이 아직도 육량등급에 의해 좌 우되고 있음을 말해주고 있다. 다시 말하자면, 현행 육량 등급제는 도체품질을 반영하는 기준 이라기보다는 단순히 유통업자가 요구하는 '크기 맞추기' 명목으로 생산자로부 터 빼앗아가는 '불공정 할인금'으로 해석될 수도 있다. 따 라서 도체등급이 명실상부한 품질의 척도가 되기 위해서 는 $125 \sim 140 \mathrm{~kg}$ 고체중 비육돈으로부터 산출되는 도체의 등급 기준을 따로 정하거나 현행 상위 (A \& B) 육량등급 에 허용되는 도체중 범위를 고체중 도체가 포함될 수 있 게 확장해야 마땅할 것이고, 그렇지 않다면 육량등급별 $\mathrm{kg}$ 당 도체가 차이를 현행보다 훨씬 낮추거나 폐지해야 마땅 할 것으로 사료된다.

결론적으로 $110 \mathrm{~kg}$ 보다는 $125 \mathrm{~kg}$ 혹은 그 이상의 체중 에서 도살했을 때 생산효율은 물론 도체품질이 향상될 수 있고, $3.2 \mathrm{Mcal}$ (중에너지) 대비 $3.0 \mathrm{Mcal}$ (저에너지) $\mathrm{DE} / \mathrm{kg}$ 의 에너지를 함유한 사료를 급여하면 도체등급과 도체품 질이 다소간 향상될 가능성이 있다는 것을 본 연구결과는 보여주고 있다. 본 연구와 선행연구 (박 등, 2009)의 연구 결과를 종합하면, 도체의 육량등급을 무시하고 육질만을 고려할 때 도살체중을 제한하는 제 1차 요인은 등지방두 께인 것으로 판단된다. 본 관점에서 중에너지사료를 급여 했을 때 암퇘지와 거세돼지의 한계도살체중은 당초의 결 론 (이 등, 2006)대로 각각 135 및 $125 \mathrm{~kg}$ 수준일 것으로 예측된다. 저에너지사료를 쓸 경우에는 두 성에서 공히 무리 없이 $5 \mathrm{~kg}$ 의 도살체중을 증가시킬 수 있을 것으로 예상되고, 한계도살체중에서의 등지방두께는 23 25 mm 범 위가 될 것으로 예측된다. 비육돈의 한계도살체중 예측치 는 삼겹살의 지방 함량, 지방층:근육층 비율과 기호도 및 가열육의 'eating quality' 변수 등에 대한 관능평가 결과를 종합적으로 고려해도 등지방두께를 기준으로 했을 때와 비슷한 결론에 도달한다. 그러나 육량등급이 엄격히 적용 되고 있는 현행 도체등급 제도 하에서는 $80 \sim 90 \mathrm{~kg}$ 의 체중 부터 3.0 3.2 Mcal DE/kg의 비육돈 사료를 급여할 때 도체 의 품질 및 수익성을 극대화할 수 있는 출하체중은 성에 관계없이 $122 \sim 127 \mathrm{~kg}$ 범위일 것으로 사료된다. 따라서 130 $\mathrm{kg}$ 혹은 그 이상 생체중의 '큰 돼지'를 생산하기 위해서는 현행 육량등급제를 뛰어넘을 수 있는 독특한 유통체계의 출현이 요망된다. 


\section{V. 요 약}

생체중 $80.2 \pm 0.2 \mathrm{~kg}$ 의 $(\mathrm{Y} \times \mathrm{L}) \times \mathrm{D}$ 교잡종 암퇘지와 거세 돼지에게 "중에너지” 혹은 “저에너지” $(3.2$ vs $3.0 \mathrm{Mcal}$ $\mathrm{DE} / \mathrm{kg}$ ) 사료를 급여하고 110,125 , 혹은 $138 \mathrm{~kg}$ 에 도축한 다음 이들 도체의 주요 부분육에 대한 이화학적 및 관능 품질 특성을 2 (성) $\times 2$ (사료 $) \times 3$ (도살체중) 요인분석 실험 설계 하에 본 실험을 수행하였다. 일당증체량과 일당사료 섭취량은 암퇘지에서보다 거세돼지에서 컸고 $(\mathrm{P}<0.01), 110$ $\mathrm{kg}$ 도살체중 구보다 125 및 $138 \mathrm{~kg}$ 구가 컸다 $(\mathrm{P}<0.01)$. 또 한 일당증체량과 사료효율은 중에너지 구가 저에너지 구 보다 컸던 $(\mathrm{P}<0.01)$ 반면 일당사료섭취량은 저에너지 구가 중에너지 구보다 컸다 $(\mathrm{P}<0.01)$. 등지방두께는 도살체중이 증가할수록 증가하였으나 $(\mathrm{P}<0.01)$ 성 혹은 사료의 영향을 받지는 않았다. 도체의 지방침착도는 암퇘지와 저에너지 구가 각각 거세돼지와 중에너지 구보다 높았다 $(\mathrm{P}<0.01)$. 육질등급은 저에너지 구가 중에너지 구보다 우수하였으나 도살체중의 영향은 받지 않은 반면 육량등급은 일차적으 로 $\mathrm{A}$ 와 $\mathrm{B}$ 등급에 요구되는 도체중 상한선 때문에 도살체 중 $125 \mathrm{~kg}$ 과 $138 \mathrm{~kg}$ 사이 급격히 저하되었다. 삼겹살, 뒷다 리 및 등심의 $\mathrm{pH}$, 육즙참출율 및 색깔관련 변수 등을 포 함한 이화학적 특성에 있어서는 비록 몇몇 경우에는 통계 적인 유의성이 발견되기는 하였으나 품질적인 척도에 있 어서는 어느 처리요인의 영향도 받지 않았다. 관능평가에 서 삼겹살 신선육의 기호도는 어느 처리 요인에 의해서도 영향 받지 않았다. 뒷다리 신선육의 상강도는 중에너지 대비 저에너지 구에서 높았고 $(\mathrm{P}<0.01)$ 도살체중 $110 \mathrm{~kg}$ 과 $125 \mathrm{~kg}$ 사이 증가하는 경향을 보였으며 $(\mathrm{P}=0.10)$, 등심에서 는 이들 두 도살체중 사이 본 변수의 증가는 유의성이 있 었다 $(\mathrm{P}<0.01)$. 가열육에서는 삼겹살과 뒷다리의 기호도에 서 저에너지 구가 중에너지 구보다 우수하였으나 도살체 중은 세 부위 모두에서 본 연구에서 평가된 모든 관능품 질 특성에 영향을 미치지 않았다. 결론적으로 이상의 결 과는 도체의 품질을 저하시키지 않고 도살체중을 $138 \mathrm{~kg}$ 까지 높일 수 있고, 저에너지 사료는 도체 및 주요 부분 육 품질에 다소간의 유익한 효과가 있음을 시사한다.

\section{VI. 사 사}

본 연구는 지식경제부/한국산업기술평가원, 씨제이제일 제당주식회사 및 태원농장이 지원한 진주산업대학교 동물 생명산업센터의 연구개발과제 사업비 지원으로 수행되었 습니다. 저자 일동은 공시사료 생산과 도체분석에 도움을 주신 부경양돈농협 사료사업본부 및 육가공사업본부 관계 자 여러분들과 부분육에 대한 이화학적 특성 분석과 관능 평가에 참가한 경상대학교 식육과학연구실 대학원생 및 연구원들께 감사드립니다.

\section{VII. 인 용 문 헌}

1. Cisneros, F., Ellis, M., McKeith, F. K., McCaw, J. and
Fernando, R. L. 1996. Influence of slaughter weight on growth and carcass characteristics, commercial cutting and curing yields, and meat quality of barrows and gilts from two genotypes. J. Anim. Sci. 74:925-933.

2. Joo, S. T., Kauffman, R. G., Kim, B. C. and Park, G. B. 1999. The relationship of sarcoplasmic and myofibrillar protein solubility to colour and water-holding capacity in porcine longissimus muscle. Meat Sci. 52:291-297.

3. Kim, Y. S., Kim, S. W., Weaver, M. A. and Lee, C. Y. 2005. Increasing the pig market weight: world trends, expected consequences and practical considerations. Asian-Aus. J. Anim. Sci. 18:590-600.

4. Latorre, M. A., Lazaro, R., Valencia, D. G., Medel, P. and Mateos, G. G. 2004. The effects of gender and slaughter weight on the growth performance, carcass traits and meat quality characteristics of heavy pigs. J. Anim. Sci. 82:526-533.

5. Lee, C. Y., Lee, H. P., Jeong, J. H., Baik, K. H., Jin, S. K., Lee, J. H. and Sohn, S. H. 2002. Effects of restricted feeding, low-energy diet, and implantation of trenbolone acetate plus estradiol on growth, carcass traits, and circulating concentrations of insulin-like growth factor (IGF)-I and IGF-binding protein-3 in finishing barrows. J. Anim. Sci. 80:84-93.

6. Martin, A. H., Sather, A. P., Fredeen, H. T. and Jolly, R. W. 1980. Alternative market weights for swine. II. Carcass composition and meat quality. J. Anim. Sci. 50:699-705.

7. Monin, G., Larzul, C., Le Roy, P., Culioli, J., Rousset-Akrim S., Talmant, A., Touraille, C. and Sellier, P. 1999. Effects of the halothane genotype and slaughter weight on texture of pork. J. Anim. Sci. 77:408-415.

8. NASS. 2008. Hogs: Commercial Slaughter Average Liveweight by Month and Year, US. National Agricultural Statistics Service. http://www.nass.usda.gov/Charts_and_Maps

9. NRC. 1998. Nutrient Requirements of Swine. 10th ed. National Academy Press, Washington, DC.

10. SAS. 1996. SAS User's Guide: Statistics. SAS Inst., Inc., Cary, NC, USA.

11. 농림부. 2005. “식육의 부위별 - 등급별 및 종류별 구분방법 중 개정고시” 농림부 고시 제 2005-50호.

12. 농림부. 2007. “축산물등급판정세부기준” 농림부고시 제 200740호.

13. 박만종, 정진연, 하덕민, 박재완, 심태건, 양한술, 박병철, 주 선태, 이철영. 2009. 저에너지 사료로 비육된 돼지에서 도살 체중과 성장성적 및 육질과의 관계. 한국동물자원과학회지 51(2):135-142.

14. 박만종, 하덕민, 신호원, 이상훈, 김원기, 하승호, 양한술, 정 진연, 주선태, 이철영. 2007. '고체중' 출하돈의 성장효율, 도 체 품질 특성 및 수익성. 한국동물자원과학회지 49:459-470.

15. 이철영, 권오천, 하덕민, 신호원, 이제룡, 하영주, 이진희, 하 승호, 김원기, 김광위, 김두환. 2006. $110 \mathrm{~kg}$ 대비 $130 \mathrm{~kg}$ 에 도 축된 비육돈의 성장효율, 도체품질 특성 및 수익성. 한국동물 자원과학회지 48:493-502.

16. 이철영, 김민호, 하덕민, 박재완, 오관용, 이제룡, 하영주, 박 병철. 2007. 비육후기 사료의 에너지 수준이 '고체중' 출하돈 의 성장효율 및 도체특성에 미치는 영향. 한국동물자원과학 회지 49:471-480.

(접수일자 : 2009. 3. 10. / 수정일자 : 2009. 4. 8. /

채택일자 : 2009. 4. 11.) 